\title{
Policy Preferences and Expertise in Canadian Tax Adjudication
}

\author{
Benjamin Alarie and Andrew James Green
}

Version Publisher's version

Publisher's Statement Reproduced from the Canadian Tax Journal: Alarie, Benjamin and Green, Andrew James, Policy Preferences and Expertise in Canadian Tax Adjudication (October 27, 2014). Canadian Tax Journal/Revue Fiscale Canadienne, Vol. 62, No. 4, 2014, 985-1027. http://dx.doi.org/10.2139/ssrn.2105785.

With permission from Thompson Reuters Canada.

\section{How to cite TSpace items}

Always cite the published version, so the author(s) will receive recognition through services that track citation counts, e.g. Scopus. If you need to cite the page number of the author manuscript from TSpace because you cannot access the published version, then cite the TSpace version in addition to the published version using the permanent URI (handle) found on the record page.

This article was made openly accessible by $U$ of $T$ Faculty. Please tell us how this access benefits you. Your story matters. 


\title{
Policy Preferences and Expertise in Canadian Tax Adjudication
}

\author{
Benjamin Alarie and Andrew J. Green*
}

\section{PRÉ CIS}

Tant les contribuables que les gouvernements tentent de demeurer au fait des diverses sources complexes relatives à la législation fiscale et de les appliquer dans une multitude de contextes variés. Compte tenu du risque de confusion et de désaccord (en plus des enjeux financiers parfois importants qui y sont rattachés), il est approprié d'avoir un processus grâce auquel les contribuables peuvent interjeter appel des décisions rendues par le gouvernement auprès d'un groupe d'experts pouvant fournir des solutions rationnelles et réfléchies faisant autorité aux différends en matière d'impôt. Pour cette raison, le Canada, comme les États-Unis, a une cour d'impôt spécialisée qui se consacre à l'audition des appels des décisions de l'administration fiscale. Pourtant, il y a lieu de croire que dans les deux pays, les juges de causes fiscales peuvent être influencés par leur propre orientation politique ou d'autres facteurs étrangers au « véritable » bien-fondé juridique lorsqu'ils rendent leurs décisions. Cet article examine des appels à l'égard de cotisations fiscales au Canada pour comprendre l'influence relative de l'expertise judiciaire en fiscalité et les orientations politiques des juges sur les décisions de la Cour canadienne de l'impôt et de la Cour d'appel fédérale. Les auteurs décrivent d'abord les institutions et les processus liés aux appels en matière d'impôt. Ils analysent ensuite l'incidence de l'expertise judiciaire et des orientations politiques sur les résultats des appels en matière d'impôt, en se basant sur environ 3400 décisions de la Cour canadienne de l'impôt de 2000 à 2006 incluant, le cas échéant, les appels connexes à la Cour d'appel fédérale et à la Cour suprême du Canada. Les auteurs discutent des trois résultats principaux de cette étude : 1) les orientations politiques des juges importent, mais dans une certaine mesure seulement; 2) les ressources importent beaucoup; et 3) il y a des dynamiques concernant l'affirmation des appels par la Cour d'appel fédérale qu'il est difficile d'expliquer, bien qu'un désir d'éviter la crainte de partialité soit possible.

\section{A B S T R A C T}

Taxpayers and governments alike struggle to stay on top of the various complex sources of tax law and to apply them in a myriad of contexts. Given the potential for confusion and disagreement (not to mention the sometimes large financial stakes involved), it is

\footnotetext{
* Of the Faculty of Law, University of Toronto (e-mail: ben.alarie@utoronto.ca; a.green@ utoronto.ca).
} 
appropriate to have a process for taxpayers to appeal government decisions to an expert body that can provide authoritative, reasoned, and rational solutions to tax disputes. For this reason Canada, like the United States, has a specialized tax court dedicated to hearing appeals from decisions of the tax administration. Yet there is some evidence in both countries that judges in tax cases may be influenced by their own personal policy preferences or other factors extraneous to the "true" legal merits in deciding appeals. This article examines appeals from tax assessments in Canada to understand the relative influence of judicial tax expertise and the policy preferences of judges on decisions at the Tax Court of Canada and the Federal Court of Appeal. The authors first describe the institutions and processes for tax appeals. They then analyze the impact of judicial expertise and policy preferences on outcomes of tax appeals, drawing on approximately 3,400 decisions of the Tax Court of Canada in the period 2000-2006 and including, where applicable, the related appeals to the Federal Court of Appeal and the Supreme Court of Canada. The authors arrive at and discuss three main results of the study: (1) policy preferences of judges matter, but not that much; (2) resources matter-a lot; and (3) there are dynamics relating to affirmation of appeals by the Federal Court of Appeal that are difficult to explain, although a desire to avoid the apprehension of bias is possible.

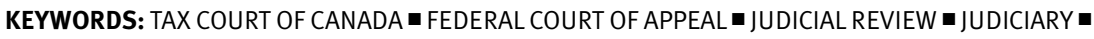
ADMINISTRATIVE LAW — LITIGATION

\section{O N T E N TS}

Introduction

Tax Adjudication in Canada

Appealing Tax Decisions $\quad 993$

Tax Appeals $\quad 996$

Tax Judges $\quad 998$

Screens, Politics, and Expertise $\quad 999$

$\begin{array}{lr}\text { The Tax Court Decision } & 1000\end{array}$

$\begin{array}{ll}\text { The Appeal Rate } & 1007\end{array}$

The Affirmation Rate 1010

$\begin{array}{ll}\text { Judging the Taxman } & 1016\end{array}$

$\begin{array}{lll}\text { Appendix A Glossary of Variables } & 1018\end{array}$

$\begin{array}{lll}\text { Appendix B } & \text { Regression Tables } & 1020\end{array}$

\section{INTRODUCTION}

Tax law is complicated. The current consolidated version of the federal Income Tax $\mathrm{Act}^{1}$ is the most detailed statute that has ever existed in Canada. Moreover, the prospects for future simplification are bleak. The complexity of the legislation is complemented by a constantly expanding set of supplementary materials: regulations from Cabinet; interpretation bulletins, folios, and other sources of administrative guidance from the Canada Revenue Agency (CRA); comfort letters issued by the

1 RSC 1985, c. 1 (5th Supp.), as amended. 
Department of Finance; and judgments of the courts explaining how specific provisions ought to be interpreted and applied. Taxpayers and the CRA struggle to stay on top of these various sources and to apply them in a wide variety of contexts. Given the potential for confusion and disagreement (not to mention the sometimes large financial stakes involved), it is appropriate to have a process for taxpayers to appeal decisions of the tax administration to an expert body that can provide authoritative, reasoned, and rational solutions to tax disputes. Yet there is some evidence in both Canada and the United States that judges in tax cases may be influenced by their own personal policy preferences or other factors extraneous to the "true" legal merits of the positions advanced by the respective parties. ${ }^{2}$

In Canada, the Tax Court of Canada hears challenges to CRA decisions. This study expands on earlier research to examine in more detail how policy preferences and the expertise of judges influence the outcomes of such challenges both at the Tax Court and on appeal to the Federal Court of Appeal. Most previous articles analyze decision making at a single level (such as Schneider's study of US appellate tax decisions), ${ }^{3}$ or how an outcome at one level affects a decision at a higher level (such as Hwong's study of Supreme Court of Canada tax decisions). ${ }^{4}$ The first kind of study is not sensitive to the treatment of decisions on appeal, thereby missing an important dimension of tax adjudication. The second kind of study ignores the cases that are not appealed, and thus ignores the vast majority of tax cases decided. This article extends the existing analysis by examining all decisions of the Tax Court of Canada in the period 2000-2006, including, where applicable, how those decisions were treated on further appeal. For this purpose, we draw together general work on judicial decision making and the empirical work on the Canadian and US tax courts and administrative law. We take account of the policy preferences of the Tax Court of Canada judges and of the judges hearing appeals from the Tax Court, along with other factors that affect the initial outcome and the appeal. Further, in contrast to prior

2 See, for example, in the US context, Robert M. Howard, "Comparing the Decision Making of Specialized Courts and General Courts: An Exploration of Tax Decisions" (2005) 26:2 7ustice System fournal 135-48; Nancy Staudt, Lee Epstein, and Peter Wiedenbeck, "The Ideological Component of Judging in the Taxation Context" (2006) 84:7 Washington University Law Review 1797-1821; and Mark P. Altieri, Jerome E. Apple, Penny Marquette, and Charles K. Moore, "Political Affiliation of Appointing President and the Outcome of Tax Court Cases" (2001) 84:6 Fudicature 310-25. In the Canadian context, see Cynthia L. Ostberg and Matthew E. Wetstein, "Economic Cases and the Attitudinal Model in the Canadian Supreme Court," paper presented to the Midwest Political Science Association 62d annual national conference, April 15-18, 2004; Thaddeus Hwong, "A Quantitative Exploration of Judicial Decision Making in Canadian Income Tax Cases" (PhD thesis, York University, 2006); and Thaddeus Hwong, "An Exploration of Influences of Sociodemographic Characteristics of Supreme Court Justices in Judicial Decision-Making in Income Tax Cases, 1920-2003" (2009) 33:1 Manitoba Law fournal 151-77.

3 See, for example, Daniel M. Schneider, "Using the Social Background Model To Explain Who Wins Federal Appellate Tax Decisions: Do Less Traditional Judges Favor the Taxpayer?" (2005) 25:1 Virginia Tax Review 201-49. See also infra note 17 and the related text.

4 Hwong, "A Quantitative Exploration of Judicial Decision Making," supra note 2. 
studies, we examine the influence of expertise and political preferences through an analysis of three different decisions in tax challenges: the decision by the Tax Court; the decision whether or not to appeal the Tax Court ruling; and the decision on the appeal. The result is a more complete picture of the influences on judicial decision making throughout the tax appeal process and in appeals of administrative decisions more generally. We find that while policy preferences of judges do matter, they do not have a large impact on outcomes of challenges to tax decisions. By contrast, the resources of the parties to the litigation have a much greater effect on outcomes.

As suggested above, the existing empirical studies of Supreme Court decisions in Canada and the United States have found that justices tend to be influenced by their personal policy preferences in different areas of law, including tax law. ${ }^{5}$ Staudt et al., for example, studied US Supreme Court tax decisions in the period 1941-2006. ${ }^{6}$ They examined the correlation between voting of justices in tax cases and a measure of the political ideology of justices (Segal-Cover scores, which are based on an analysis of newspaper articles prior to and at the time of the appointment of justices to the Supreme Court). While the authors found no correlation between the Segal-Cover scores and justices' voting in all tax cases, they did find an impact when individual taxpayer cases were considered separately from corporate taxpayer cases. Judges who were more liberal in terms of the Segal-Cover scores were more likely to vote in favour of the government in corporate taxpayer cases than justices with more conservative Segal-Cover scores.

More recently, Blank and Staudt ${ }^{7}$ and Staudt ${ }^{8}$ have examined how political preferences of judges interact with the economic and political context to influence US Supreme Court decisions. Blank and Staudt (2012) analyzed the decisions of the US Supreme Court in appeals in which corporate tax abuse was alleged over the 19192011 period. They found that higher levels of defence spending were correlated with pro-government decisions. They also found that the win rate for the government

5 For the United States, see generally Jeffrey A. Segal and Harold J. Spaeth, The Supreme Court and the Attitudinal Model Revisited (Cambridge, UK: Cambridge University Press, 2002); and Andrew D. Martin and Kevin M. Quinn, "Dynamic Ideal Point Estimation via Markov Chain Monte Carlo for the U.S. Supreme Court, 1953-1999" (2002) 10:2 Political Analysis 134-53. For Canada, see Benjamin R.D. Alarie and Andrew J. Green, "The Reasonable Justice: An Empirical Analysis of Frank Iacobucci's Career on the Supreme Court of Canada" (2007) 57:2 University of Toronto Law Fournal 195-226; Benjamin Alarie and Andrew J. Green, "Should They All Just Get Along? Judicial Ideology, Collegiality, and Appointments to the Supreme Court of Canada" (2008) 58 University of New Brunswick Law fournal 73-91; Benjamin Alarie and Andrew Green, "Policy Preference Change and Appointments to the Supreme Court of Canada" (2009) 47:1 Osgoode Hall Law Fournal 1-46; and C.L. Ostberg and Matthew E. Wetstein, Attitudinal Decision Making in the Supreme Court of Canada (Vancouver: University of British Columbia Press, 2007).

6 Staudt et al., supra note 2.

7 Joshua D. Blank and Nancy Staudt, “Corporate Shams" (2012) 87:6 New York University Law Review 1641-1712.

8 Nancy Staudt, The Fudicial Power of the Purse: How Courts Fund National Defense in Times of Crisis (Chicago: University of Chicago Press, 2011). 
was lower in the period after 1986 (the year Justice Scalia was appointed). ${ }^{9}$ Staudt (2011) analyzed a random sample of appellate court tax decisions as well as US Supreme Court tax decisions from 1909-2010. She found that increased defence spending was positively correlated with pro-government decisions. In addition, she found that in times of war, if a consistent message for increased spending was being sent by both the legislature and executive, then the judges in the sample tended to find for the government to a greater extent than for the taxpayer. Further, liberal judges tended to be more influenced by wartime conditions, while conservative judges were more influenced by monetary cues (that is, defence spending). Staudt found these effects only at the Supreme Court level. Thus, she found that while political ideology did not exert a strong direct effect on judicial decision making in tax cases, it did influence which sociopolitical cues were responded to by different justices.

Similarly, Ostberg and Wetstein have identified an influence of political ideology on Supreme Court of Canada decision making in tax cases. ${ }^{10}$ Examining Supreme Court of Canada tax decisions between 1984 and 2002, they found that liberalism scores (which, like Segal-Cover scores, are based on information derived from newspaper accounts from the time when justices were appointed) were correlated with pro-government votes by judges in non-unanimous decisions. Hwong studied the Supreme Court of Canada over a longer period, from 1920 to 2003. ${ }^{11}$ Using the party of the appointing prime minister as the proxy for political ideology (rather than the Ostberg-Wetstein liberalism scores), he found no consistent effect of political ideology on judicial decision making in tax appeals.

Instead of studying the tax decisions of supreme courts, some studies have focused on judicial decision making at the lower-court level, either a specialized tax court or an appellate court. Altieri et al. examined decisions of the US Tax Court between 1993 and 1997, distinguishing between judges appointed by Democratic and Republican presidents. ${ }^{12}$ They found that judges appointed by Republican presidents were more likely to find for the taxpayer than those appointed by Democratic presidents. However, judges appointed by Democratic presidents were also more likely to have been employed by government. Employment by the government in the researchers' dataset was also associated with an increased likelihood of finding for the government. Unfortunately, Altieri et al. were unable to accurately separate out the effects of political preferences and past work experience, owing to colinearity.

9 Presumably in part owing to Justice Scalia's influence, the period following his appointment has been associated with a more literal style of statutory interpretation on the court (though not by a statistically significant margin).

10 Ostberg and Wetstein, supra note 5.

11 Hwong, "An Exploration of Influences of Sociodemographic Characteristics," supra note 2.

12 Altieri et al., supra note 2. Early research in this area includes Stuart S. Nagel, "Political Party Affiliation and Judges' Decisions" (1961) 55:4 American Political Science Review 843-50. Nagel studied the decisions of Democratic and Republican judges issued in 1955. He found that Democratic judges were more likely to find in favour of the government in tax cases. 
Studying the US Tax Court and the US district courts in 1996 and 1997, Howard (2005) also found a connection between political ideology and voting. ${ }^{13}$ He found that more liberal courts (based on a metric that included the party of the nominating president and the state ideology) were more likely to find in favour of the government than conservative courts. Further, he found that liberal judges were more likely to find against the taxpayer in cases of tax protest and tax fraud. The impact of ideology was greater in decisions of the Tax Court than in those of the US district courts, which relied more on precedent.

There has been little work done on lower-court tax decisions in Canada and how these decisions are influenced by the ideology of the particular judges. As discussed further in the next section, in Canada appeals of decisions go first to the Tax Court of Canada, with the possibility of further appeals by the taxpayer or the government to the Federal Court of Appeal and the Supreme Court of Canada. Perhaps the only study to examine the Tax Court of Canada's decision making is the one by Hwong (2006). ${ }^{14}$ Hwong analyzed 3,867 votes by 34 judges in decisions of the Tax Court of Canada in the period 1983-2004. He found that appointment by a Conservative prime minister was associated with voting in favour of taxpayers (and that appointment by a Liberal prime minister was associated with voting in favour of the government).

Prior studies have thus tended to find some connection between the policy preferences of individual judges and how they vote in tax cases. Moving on to other biographical considerations, a number of studies have also examined how factors such as expertise and experience influence judicial decision making in tax cases. As noted above, for example, in the US context Altieri et al. found that recent employment by the government tends to make judges more likely to vote in favour of the government. However, in a study of US Tax Court judges using data from around the same time period as Altieri (between 1995 and 1997), Maule found no discernible influence of prior government work experience on voting among Tax Court judges. ${ }^{15}$

Schneider examined both the US Tax Court and certain district courts in the period 1993-1997. ${ }^{16} \mathrm{He}$ found that if a judge attended an elite college, he or she was more likely to vote in favour of the taxpayer. Further, judges who had a shorter tenure on the bench were more likely to vote in favour of the taxpayer. In later studies examining appellate court decisions between 1996 and 2000, Schneider found that personal characteristics of the judges were in general not predictive of the outcomes of the

13 Howard, supra note 2.

14 Hwong, "A Quantitative Exploration of Judicial Decision Making," supra note 2.

15 James Edward Maule, "Instant Replay, Weak Teams, and Bad Calls: An Empirical Study of Alleged Tax Court Judge Bias" (1999) 66:2 Tennessee Law Review 351-426.

16 See Daniel M. Schneider, "Assessing and Predicting Who Wins Federal Tax Trial Decisions" (2002) 37:2 Wake Forest Law Review 473-529. See also Daniel M. Schneider, "Empirical Research on Judicial Reasoning: Statutory Interpretation in Federal Tax Cases" (2001) 31:2 New Mexico Law Review 325-58, examining the use of "practical reasoning" by judges on the Tax Court and certain district courts during the same period. 
cases. ${ }^{17} \mathrm{He}$ concluded that the impact of personal characteristics on decisions of judges in tax cases was minimal.

With respect to other biographical factors in the Canadian context, Hwong's study of Supreme Court of Canada decisions between 1920 and 2003 found that Supreme Court justices who had been trial judges prior to their appointment or were educated outside Canada were more likely to find in favour of the government. ${ }^{18}$ Hwong also found some impact relating to whether the judge had founded his or her own law firm. In terms of the Tax Court of Canada, Hwong found that experience as a trial judge, post-secondary education abroad, entrepreneurial experience, and having taught law on a part-time basis were all associated with voting in favour of taxpayers. ${ }^{19}$ Further, judges were more likely to vote for the taxpayer in their earlier years on the Tax Court of Canada but against them in their later years. Hwong did not find any consistent effect on voting associated with regional ties, years in private practice, or gender.

The relationship between expertise and policy preferences is interesting in judicial decision making in general, though perhaps especially so in the context of administrative law. Tax appeals are, in effect, judicial reviews of executive decision making since they are appeals from decisions of a government agency (the CRA) to the courts. There is a constant debate in the administrative-law literature about how much the courts should defer to the executive decision maker given, in particular, that the executive decision maker likely has more expertise than the court. ${ }^{20}$ The courts attempt to maintain their role in policing the boundaries of the decisionmaking powers of executive bodies, to ensure that the decisions that are made are within the contemplation of the legislature that granted those bodies their powers. ${ }^{21}$ The executive decision maker should not be making decisions that are beyond its authority nor should it be making decisions in its own interest. At the same time, the courts realize that executive bodies have greater expertise in many areas than the generalist judges and that the legislature granted power to the executive body in order to take advantage of that expertise. ${ }^{22}$ Canadian courts-and others around the world-have been striving to strike the right balance between maintaining their oversight role and deferring to expertise where warranted.

17 See Daniel M. Schneider, "Statutory Construction in Federal Appellate Tax Cases: The Effect of Judges' Social Backgrounds and of Other Aspects of Litigation" (2003) 13 Washington University Fournal of Law \& Policy 257-304; and Schneider, supra note 3.

18 Hwong, "An Exploration of Influences of Sociodemographic Characteristics," supra note 2.

19 Hwong, "A Quantitative Exploration of Judicial Decision Making," supra note 2.

20 See Andrew Green, "Regulations and Rule Making: The Dilemma of Delegation," in Colleen M. Flood and Lorne Sossin, eds., Administrative Law in Context, 2d ed. (Toronto: Emond Montgomery, 2013), 125-46.

21 See Audrey Macklin, "Standard of Review: Back to the Future?" in Administrative Law in Context, supra note 20, 279-321; and Sheila Wildeman, "Pas de Deux: Deference and Non-Deference in Action," ibid., 323-80.

22 Green, supra note 20, and Macklin, supra note 21. 
As an empirical matter, this review role for the courts has not been studied extensively. A number of studies have found that there is in general a high affirmation rate for executive decisions-that is, that courts are more likely to affirm executive decisions than to reverse them. In the United States, a key administrative-law doctrine stems from Chevron USA, Inc. v. NRDC. ${ }^{23}$ The Chevron doctrine attempts to define when deference is due to agency interpretations of statutes. There is evidence of ideological voting in the application of the Chevron framework in more general studies of judicial review. ${ }^{24}$ One of the key findings in the empirical literature on administrative law is that the courts have a tendency to affirm around two-thirds of agency decisions. ${ }^{25}$ For example, Czarnezki found "a strong willingness to defer, under any doctrine or framework, to agency action when environmental scientific expertise is required." ${ }^{26}$ Courts in the United States, at least in the context of statutory interpretation, are more likely than not to allow agency decisions to stand, regardless of their ideology. In Canada, Green ${ }^{27}$ has found a similar high affirmation rate in the context of judicial reviews under the Canadian Environmental Assessment Act. ${ }^{28}$

The literature has been somewhat mixed on whether administrative-law doctrines or principles have been used to obtain particular outcomes-for example, whether judges chose more deferential standards of review when they wanted to uphold an agency decision. Miles and Sunstein found that at the US Supreme Court the decision to apply the Chevron doctrine was modestly related to the ideology of the judge, with Democratic-appointed judges being more likely to apply Chevron for agency decisions coded as liberal than were Republican appointees. ${ }^{29}$ Czarnezki, on the

23467 US 837 (1984).

24 See Thomas J. Miles and Cass R. Sunstein, "Do Judges Make Regulatory Policy? An Empirical Study of Chevron" (2006) 73:33 University of Chicago Law Review 823-81; see also Kiki Caruson and J. Michael Bitzer, "At the Crossroads of Policymaking: Executive Politics, Administrative Action, and Judicial Deference by the DC Circuit Court of Appeals (1985-1996)" (2004) 26:3-4 Law \& Policy 347-69; and Martha Ann Humphries and Donald R. Songer, "Law and Politics in Judicial Oversight of Federal Administrative Agencies" (1999) 61:1 Fournal of Politics 207-20.

25 See, for example, Miles and Sunstein, supra note 24, at 853 (finding that circuit courts affirm approximately 62 percent of Environmental Protection Agency decisions and 70 percent of National Labor-Relations Board decisions, although the rates vary slightly by party affiliation); Jason J. Czarnezki, “An Empirical Investigation of Judicial Decisionmaking, Statutory Interpretation and the Chevron Doctrine in Environmental Law" (2008) 79:3 University of Colorado Law Review 767-823, at 783 (finding an affirmation in his data of approximately 69 percent); and Peter H. Schuck and E. Donald Elliott, "To the Chevron Station: An Empirical Study of Federal Administrative Law" [1990] no. 5 Duke Law Fournal 984-1077 (finding a post-Chevron affirmation rate of over 80 percent).

26 See Czarnezki, supra note 25 , at 771.

27 Andrew Green, "Discretion, Judicial Review and Environmental Policy: Does the Federal Court Constrain Decisions Under CEAA?" June 4, 2013 (unpublished manuscript on file with the author).

28 Canadian Environmental Assessment Act, SC 2012, c. 19.

29 Miles and Sunstein, supra note 24, at 844. 
other hand, found only "very limited evidence" that the Chevron doctrine under US administrative law has been used to obtain a particular outcome. ${ }^{30}$ Green found only weak evidence to support such ideological choice of deference levels in the context of Canadian Federal Court reviews of environmental assessment decisions. ${ }^{31}$

This article builds on this earlier theoretical and empirical work relating to both judicial decision making generally and tax decisions in particular, to examine the effect of judicial policy preferences and expertise on outcomes of challenges to tax decisions. The next section provides the background, describing the institutions and processes for tax appeals, and presenting a basic overview of the data on appealsfor example, who the parties tend to be, the nature of the adjudicative process used, and general success rates. The third section of the article then examines the role of expertise and political preferences of judges in tax decisions. The Tax Court is ostensibly set up to allow specialized judges to hear appeals in a complicated area of law, yet not all Tax Court judges are tax specialists. Moreover, Tax Court judges should in theory become better at their work as they gain experience on the bench. We discuss what might be meant by ideology and expertise in this context and how it appears to affect judicial decision making. As noted above, we focus on three issues: what factors appear to influence outcomes at the Tax Court level; what factors are associated with appeals of Tax Court decisions; and what factors appear to influence outcomes on appeal. The fourth section concludes with a discussion of the implications of our findings. We find that political preferences and expertise matter, but not as much as may be expected. In addition, there is an interesting interplay of political preferences between judges at the Tax Court and the Federal Court of Appeal, with Appeal Court judges being more likely to uphold decisions of Tax Court judges who have different rather than similar political preferences. Finally, we find that resources are vitally important to each of the decision points we examine.

\section{TAX ADJUDICATION IN CANADA Appealing Tax Decisions}

The most important source of government revenue in Canada is the income tax; ${ }^{32}$ more than $\$ 200$ billion is raised each year federally and provincially through the combination of personal and corporate income taxes. A crucial aspect of the Canadian income tax system is that it is based principally on voluntary compliance and

30 Czarnezki, supra note 25, at 820 (although he notes that differences from Miles and Sunstein may be attributable in part to his use of a dataset that involves only Bush administration decisions, which may dampen Democratic appointees' willingness to defer). See also Caruson and Bitzer, supra note 24 (finding that standards of review did not appear to be chosen for ideological reasons).

31 Green, supra note 28.

32 For background on the development of the income tax and its role within Canadian fiscal arrangements, see Benjamin Alarie and Richard M. Bird, "Canada," in Claudio Sacchetto and Gianluigi Bizioli, eds., Tax Aspects of Fiscal Federalism: A Comparative Analysis (Amsterdam: International Bureau of Fiscal Documentation, 2011), 79-136. 
self-assessment. This self-assessment feature allows the system to operate at a relatively modest expenditure as compared with the revenues generated. It also places a significant responsibility on taxpayers to understand and comply with their tax obligations. This section sets out how decisions by the CRA in assessing taxpayers (what we will call "tax decisions") can be appealed internally within the CRA, and thereafter to the Tax Court of Canada and beyond.

Canadian taxpayers file their annual income tax returns with the CRA. The CRA is the government agency that is responsible for assessing and collecting income taxes, both federally and on behalf of the provinces that have entered into tax collection agreements with the federal government. In Quebec, individual and corporate taxpayers alike file returns with both the CRA and Revenu Québec, the province's counterpart to the CRA.

The CRA plays two roles with respect to the administration of the Canadian income tax system: as a tax assessor, and as a tax adjudicator. In its role as a tax assessor, the CRA is responsible for processing the information submitted by taxpayers; collating information provided by parties with reporting responsibilities; and, through audits and other means, satisfying itself of the consistency and accuracy of taxpayer self-assessments. Where there are inconsistencies or inaccuracies in the information provided by taxpayers (or where taxpayers have not supplied information), the CRA will assess taxpayers consistently with its own view of the facts and the law as applied to the taxpayer's situation.

In carrying out the agency's role as a tax adjudicator, the Appeals Branch of the CRA will consider cases in which taxpayers disagree with the CRA's assessment. Taxpayers generally have 90 days from the date of issuance of an assessment within which to submit a notice of objection stating the basis of their disagreement with the assessment. When a notice of objection is filed, representatives of the Appeals Branch who were not involved in the original assessment formally review the assessment and may modify or reverse it where they find it to be inconsistent with the facts or the law. In many cases, the CRA's internal disposition of a notice of objection will be the end of the matter for the taxpayer, either because the taxpayer's objection to the original assessment was sustained, or because the taxpayer believes that further appeal would be fruitless.

In the event that the CRA's internal review of a notice of objection is not satisfactory to a taxpayer, the taxpayer has the right to appeal to the Tax Court of Canada within 90 days of the CRA's issuance of a notice of reassessment or notice of confirmation. The Tax Court of Canada is a federal court of superior jurisdiction, and has the jurisdiction to decide appeals from assessments under a number of statutes, including the Income Tax Act, the Excise Tax Act, ${ }^{33}$ and the Employment Insurance Act. ${ }^{34}$

33 RSC 1985 , c. E-15, as amended.

34 SC 1996, c. 23, as amended. 
At the Tax Court, there are two distinct procedures that are available to taxpayers, the general procedure and the informal procedure. The informal procedure is designed to be a streamlined process to resolve appeals. In appeals involving income taxes, the informal procedure is available only when the amount of federal tax and penalties in dispute (not including interest) is $\$ 25,000$ or less (or involves losses under the Income Tax Act of \$50,000 or less). The informal procedure allows for taxpayers to represent themselves, to be represented by a lawyer, or to be represented by an agent (often an accountant). The informal procedure also allows for flexible departures from the ordinary rules-of-evidence law.

The general procedure is always available to taxpayers if they decide to pursue it. Under the general procedure, a more conventional approach to the rules of representation and evidence is observed; parties are encouraged to have legal representation and are generally unable to use agents to represent them. Under the general procedure, the Tax Court observes the ordinary rules of evidence.

The chief justice of the Tax Court assigns judges to cases. The assignment is not random, but is typically regarded as an administrative function that depends on balancing the workload of justices, ensuring continuity of a judge on a particular case (this applies from the perspective of case management and settlement conferences, etc.), and convenience linked to geographical considerations..$^{35}$ Our impression is that decisions about docket assignment are likely to be reasonably balanced and unbiased.

Regardless whether taxpayers use the general or the informal procedure at the Tax Court, an appeal from a decision of that court may be possible to the Federal Court of Appeal, which has exclusive jurisdiction to hear such appeals. ${ }^{36} \mathrm{~A}$ small number of appeals decided by the Federal Court of Appeal are appealed further to the Supreme Court of Canada. An appeal from a judgment of the Federal Court of Appeal to the Supreme Court of Canada is not automatic; taxpayers must apply to the Supreme Court for leave to appeal, which the court may grant or deny. In the past two decades, only about 14 percent of the applications for leave to appeal to the Supreme Court in tax cases have been granted. ${ }^{37}$

35 For a discussion of these issues, see Eugene Rossiter, Wyman Webb, Ken Skingle, and Jehad Haymour, "Tax Litigation: Current Topics," in Report of Proceedings of the Sixty-Fourth Tax Conference, 2012 Conference Report (Toronto: Canadian Tax Foundation, 2013), 31:1-20.

36 Appeals from the Tax Court to the Federal Court of Appeal are limited to certain grounds, including that the Tax Court (1) acted without jurisdiction; (2) failed to observe the principles of natural justice or procedural fairness; (3) erred in law; (4) based its decision on an error in fact made in a perverse or capricious manner, or without regard to the material before it; (5) acted or did not act on fraud or perjured evidence; or (6) acted in any other way contrary to law: Federal Courts Act, RSC 1985, c. F-7, as amended, sections 27(1.2) and (1.3). Any such appeals are to be heard without delay and in a summary way: ibid., section $27(1.4)$.

37 According to data shared with the authors by the Supreme Court of Canada, from 1990 to 2011 there were 446 applications for leave to appeal in tax cases. The court granted leave to appeal in 61 (or 13.7 percent) of these cases. 


\section{Tax Appeals}

To examine judicial decisions in tax appeals, we created a database consisting of 3,411 trial decisions of the Tax Court of Canada between 2000 and 2006, along with all the appeals of these decisions to the Federal Court of Appeal and the Supreme Court of Canada.$^{38}$ For each appeal, we coded data relating to a wide range of information, including the parties to the appeal, ${ }^{39}$ whether the party was represented, ${ }^{40}$ the outcome of the appeal, ${ }^{41}$ the geographical source of the appeal, whether the case was appealed further, and the outcome of any such further appeal.

As shown in table 1, individual taxpayers were responsible for most of the appeals (82 percent) in this period, with the other principal appellants being private corporations (16 percent) and public corporations (2 percent). ${ }^{42}$ A single party (rather than multiple named appellants) brought most of these appeals, and only 5 percent of these appeals had interveners. About one-third of the appeals originated in Ontario and one-third in Quebec, with the remainder being dispersed across the rest of Canada.

In this period, more than two-thirds of the decisions of the Tax Court related to the Income Tax Act alone; the remainder concerned employment insurance, the goods and services tax (GST) (Canada's federal value-added tax), and other issues such as the Canada Pension Plan (table 1). More than half of these appeals were brought using the informal procedure rather than the general procedure and almost 90 percent of these decisions were made after a single-day hearing. Interestingly, a similar percentage of appellants were self-represented or had legal counsel, with a significant number (24 percent) employing an agent (non-lawyer) to aid in the appeal.

38 We coded all cases by the Tax Court of Canada between 2000 and 2006. We included all of the cases that were assigned a neutral citation by the Tax Court, in the form of "20YY TCC XX," and listed on the court's website. There were 4,231 such cases in this period. We dropped cases heard by deputy judges since there was less information on these judges. We also dropped decisions on interim matters, such as motions, that were occasionally assigned neutral citations. The Federal Court of Appeal and Supreme Court of Canada cases were found by noting up the neutral citations of the Tax Court of Canada decisions on several legal databases to ensure that no reported decisions on appeals from Tax Court judgments were missed.

39 We coded the "party type" of cases in the following categories: individual taxpayer; private corporation; public corporation; partnership; charitable organization; estate; government (includes all government ministries, departments, agencies, tribunals, and bodies such as municipalities); individual and corporation; individual and estate; trust; individual and government; union; individual and charity; individual and partnership; and other.

40 For representation, we used the following categories: self-represented; represented by counsel; represented by an agent; represented by counsel or an agent (but not specified); mixed representation; no one appearing; and not determined (the latter category being one decision in our sample).

41 For outcome of the Tax Court hearing, we had three categories: outcome in favour of the taxpayer; outcome against the taxpayer; and mixed outcome.

42 In this period, approximately 90 percent of the decisions were appeals of decisions of the CRA with the remaining decisions relating to motions, orders, or applications. 
TABLE 1 Characteristics of Tax Court of Canada Cases, 2000-2006

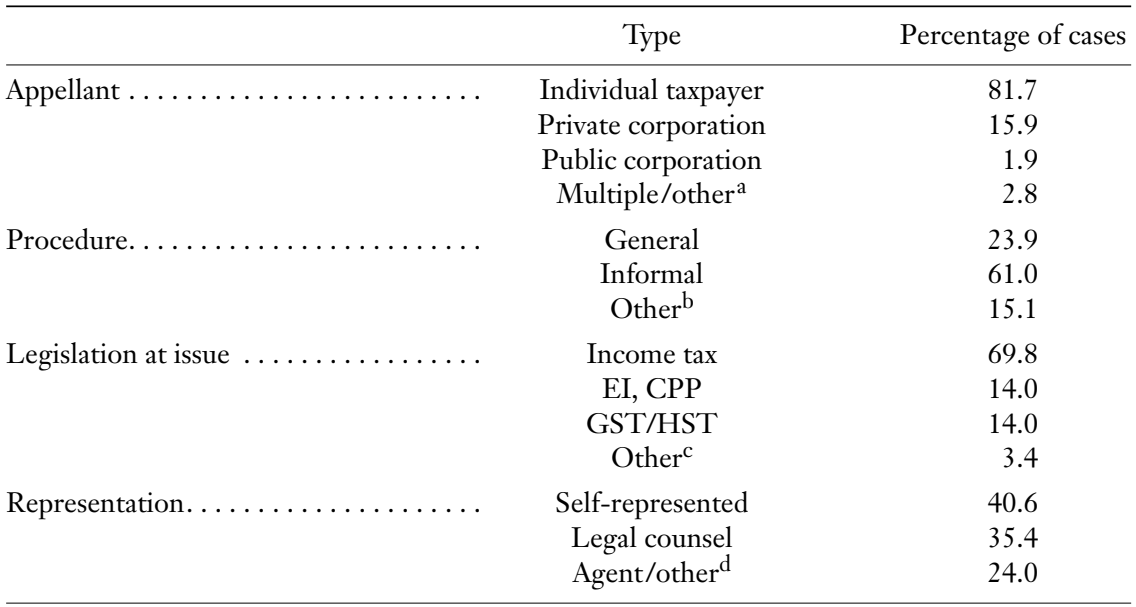

$\mathrm{EI}=$ employment insurance.

$\mathrm{CPP}=$ Canada Pension Plan .

GST/HST = goods and services tax/harmonized sales tax.

${ }^{a}$ Includes charities; estates; governments; trusts; individual and corporation; individual and estate; individual and government; union; individual and charity; individual and partnership; and other.

${ }^{b}$ Mixed representation ( 5 cases or 0.1 percent of cases) not included.

${ }^{c}$ Includes income tax benefit program; old age security; GST and income tax; EI and CPP; and other.

${ }^{\mathrm{d}}$ Includes counsel or agent (not specified); mixed representation; no one appearing; and not determined (one case)

Breaking down these appeals by their outcome, the Tax Court found against the taxpayer in slightly over half (51 percent) of the decisions during this period (table 2). There is a difference, however, across the types of party appealing. For individuals, the Tax Court found against the taxpayer in about 54 percent of the challenges, while for private corporation appellants it was the reverse, with the Tax Court finding in favour of the private corporation in about 60 percent of appeals. Public corporation appellants had an even higher success rate, winning in about 73 percent of appeals.

Between 2000 and 2006, 12.6 percent of Tax Court decisions were appealed to the Federal Court of Appeal. As shown in table 2, approximately 62 percent of the decisions that were appealed were in favour of the government at the Tax Court (that is, were appealed by the taxpayer), while the outcomes of those that were not appealed essentially mirrors the total success rate of taxpayers (with 49 percent of the decisions not appealed being in favour of the government). This means that if the government loses at the Tax Court of Canada, it is less likely to appeal the loss than are taxpayers who lose at the Tax Court.

The Federal Court of Appeal affirmed approximately 76.7 percent of the Tax Court decisions appealed, and reversed or varied approximately 23.3 percent of those decisions. However, as table 3 illustrates, the affirmation rate varies by the outcome at 
TABLE 2 Outcomes at the Tax Court of Canada and Percentage of Decisions Appealed to the Federal Court of Appeal, 2000-2006

\begin{tabular}{|c|c|c|}
\hline & $\begin{array}{l}\text { In favour of } \\
\text { government }\end{array}$ & $\begin{array}{c}\text { In favour of } \\
\text { taxpayer }\end{array}$ \\
\hline & \multicolumn{2}{|c|}{ percent } \\
\hline Outcome at Tax Court. & 51.0 & 49.0 \\
\hline Not appealed . & 49.4 & 50.6 \\
\hline Appealed & 62.1 & 37.9 \\
\hline
\end{tabular}

the Tax Court. The Federal Court of Appeal affirmed over 80 percent of the Tax Court decisions that were against the taxpayer and just under 70 percent of the decisions that were in favour of the taxpayer. This may reflect the greater selectivity of the government in pursuing appeals from decisions of the Tax Court. Of the appeals to the Federal Court of Appeal during this period, about 2 percent (10 decisions) were appealed to the Supreme Court of Canada. The Supreme Court affirmed 6 of these 10 appeals ( 60 percent).

In summary, the Tax Court tended to find for the government slightly more than half the time. The government was less likely to appeal its losses at the Tax Court than were taxpayers who lost at the Tax Court. On appeal to the Federal Court of Appeal, the affirmation rate of Tax Court decisions was much higher when the initial decision was for the government than when it was for the taxpayer.

\section{Tax Judges}

We also collected information on the judges at the Tax Court, the Federal Court of Appeal, and the Supreme Court of Canada deciding the cases in our sample. We collected information on the political party of the prime minister that appointed the judge, the experience of judges prior to sitting on the particular court, ${ }^{43}$ their tenure on the bench, and gender. In general, Tax Court judges during this period did not have prior experience on the bench (less than a third had been on the bench prior to being on the Tax Court), were overwhelmingly male ( 88 percent), and tended to have private-sector experience (over 70 percent). Most judges did not have academic tax specialization or scholarly work on tax prior to their appointment. Of the 28 Tax Court judges in our database, 15 were appointed by a Conservative prime minister and 13 by a Liberal prime minister. Recall that the chief justice of the Tax Court decides who will hear particular cases on the basis, in significant part, of workload-balancing considerations.

One question that we will discuss in the next section is whether there is a connection between the outcomes of the tax appeals during the study period and these

43 We coded for whether prior to being appointed to the Tax Court, the judge had worked in the private sector, in the public sector, and/or in academia, and whether the judge had any prior experience in tax or on the bench. 
TABLE 3 Outcomes at Tax Court of Canada and Affirmation Rates at Federal Court of Appeal, 2000-2006

\begin{tabular}{|c|c|c|}
\hline Outcome at Tax Court & $\begin{array}{l}\text { Not affirmed by } \\
\text { Court of Appeal }\end{array}$ & $\begin{array}{c}\text { Affirmed by } \\
\text { Court of Appeal }\end{array}$ \\
\hline & \multicolumn{2}{|c|}{ percent } \\
\hline For government. . & 18.4 & 81.7 \\
\hline For taxpayer. & 31.3 & 68.7 \\
\hline
\end{tabular}

personal characteristics of judges on the Tax Court. Because we use judge votes (that is, the number of decisions rendered by judges), table 4 sets out the percentage of judge votes by various characteristics of the Tax Court judges in the sample. The vast majority of judge votes were by judges who were male (about 82 percent), were tax professionals prior to joining the Tax Court (75 percent), and had private-practice experience prior to joining the Tax Court (87 percent). A slightly greater number of decisions were made by Tax Court judges appointed by Conservative prime ministers (53 percent) and by judges with public-sector experience prior to joining the Tax Court (50.5 percent). On average, the Tax Court judges in our database had 35 years of bar experience and had been on the Tax Court for almost 10 years. ${ }^{44}$

In our database, 19 Federal Court of Appeal judges heard appeals of Tax Court decisions. Eleven of these judges were appointed by Liberal prime ministers. However, Liberal appointees cast 76.6 percent of the votes in these appeals. The difference in judge votes comes from the composition of the panels hearing the appeals. The Federal Court of Appeal sits in panels of three. One-third of the panels were all Liberal appointees, almost half (46.7 percent) had two Liberal appointees and one Conservative, almost one-fifth (18.9 percent) had two Conservative appointees and one Liberal, and the remainder (about 1 percent) had three Conservative appointees. The chief justice of the court sets the panels, taking into account workload and other factors.

\section{SCREENS, POLITICS, AND EXPERTISE}

In this section, we examine three potentially overlapping determinants of the decisions of the Tax Court and of the appeals from those decisions during the study period. First, we examine the determinants of the decisions themselves, including whether either the identity of the taxpayer or the procedure followed (such as whether the taxpayer was represented, and whether the informal or the general procedure was used) was important and whether the political preferences or experience of the judges mattered. Second, we examine the screening that takes place for appeals. We analyze the appeal rates relative to the characteristics of the decision (such as the parties involved, the procedure followed, and the characteristics of the judge).

44 The mean for the Tax Court judges for experience at the bar was 35.1 years (s.d. 7.4) and for time on the Tax Court, 9.67 years (s.d. 5.5). 


\section{TABLE 4 Characteristics of Tax Court Judges as a Percentage of Judge Votes, 2000-2006}

\begin{tabular}{|c|c|}
\hline Judge characteristic & Percentage of judge votes \\
\hline 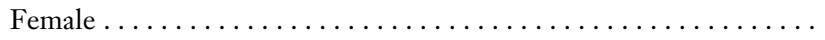 & 18.4 \\
\hline Liberal appointee. ... & 47.0 \\
\hline \multicolumn{2}{|l|}{ Prior experience } \\
\hline Tax professional. . & 75.1 \\
\hline Private practice $\ldots \ldots \ldots \ldots \ldots \ldots$ & 87.1 \\
\hline Public sector. $\ldots \ldots \ldots \ldots \ldots \ldots \ldots \ldots \ldots \ldots \ldots \ldots$ & 50.5 \\
\hline 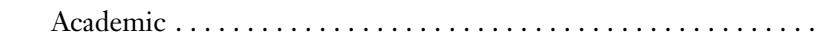 & 22.4 \\
\hline
\end{tabular}

Finally, we examine the decisions in relation to the outcome at the Federal Court of Appeal, to determine what affects the affirmation rate.

\section{The Tax Court Decision}

As we saw in the previous section, taxpayers lose at the Tax Court slightly more than half the time. However, from our database, there are differences across types of taxpayers, with individuals losing more than half the time, private corporations losing less than half of their cases, and public corporations losing less than a third. What accounts for this difference? In this section we examine the influence of three possible factors: (1) the nature of the party; (2) the procedure used; and (3) of particular interest, the judge who decided the appeal.

In order to determine the influences on the Tax Court decisions, we ran a series of regressions in which the dependent variable was whether the taxpayer won or lost at the Tax Court. ${ }^{45}$ The first question is whether there is any relationship at all between whether the taxpayer won and the appointing political party of the Tax Court judge. To examine this issue, we created an independent variable (TCCLiberalAppt) with a value of 0 if the judge was appointed by a Conservative prime minister and 1 if the judge was appointed by a Liberal prime minister. While not as pronounced as the influence of the party of the appointing president on voting in US courts, Canadian studies have found some connection between the party of the appointing prime minister and voting on the Supreme Court of Canada, particularly in some Charter areas. ${ }^{46}$ This connection has been found in terms of the tendency of judges both to

45 The dependent variable was a dummy variable with a value of 0 if the taxpayer lost and 1 if the taxpayer won.

46 See, for example, Alarie and Green, "Policy Preference Change and Appointments to the Supreme Court of Canada," supra note 5; and Benjamin Alarie and Andrew Green, "Charter Decisions in the McLachlin Era: Consensus and Ideology at the Supreme Court of Canada" (2009) 47 Supreme Court Law Review 475-511. But see Ostberg and Wetstein, supra note 5 (who find that the party of the appointing prime minister has little explanatory power at the Supreme Court level, and instead advocate for the use of an ideology score based on newspaper accounts at the time of the judge's appointment). On the United States, see Segal and Spaeth, supra note 5 . 
cast "liberal" votes and to vote with judges appointed by a prime minister of the same party. In studies of Canadian tax cases, Hwong found no relationship between the party of the appointing prime minister and voting in tax cases at the Supreme Court, but some connection at the Tax Court level. ${ }^{47}$ In terms of our database, looking only at this measure of ideology (and controlling for no other factors), a Tax Court judge appointed by a Liberal prime minister is slightly less likely to vote in favour of a taxpayer than a judge appointed by a Conservative prime minister, but the difference is not statistically significant in most specifications. ${ }^{48}$ The correct way to interpret the coefficient in column 1 of table 5 is that a Tax Court judge appointed by a Liberal prime minister is about 3 percent less likely to find in favour of a taxpayer, though the result is not statistically significant (that is, we cannot be confident that the effect is different from 0 ).

We next focused our attention on whether professional tax expertise made a difference in how a Tax Court judge decided at trial. Table 5 (column 2) also provides the results of an analysis using taxpayer success at the Tax Court as the dependent variable and various means of ideology and expertise as independent variables. The correct way to interpret the coefficients is as proportional changes in the likelihood of taxpayer success at the Tax Court, while controlling for all the other independent variables. We examined the effect on taxpayer success of years of Tax Court experience of the particular judge, whether he or she had any prior tax experience, and the nature of his or her experience prior to joining the bench (whether the experience was in private practice, the public sector, or academia). A number of interesting points arise from this analysis. First, after controlling for these various expertise factors, the success rate for taxpayers is about 41 percent (significant at the 99 percent level) - that is, where the judge is a Conservative appointee with no prior Tax Court or tax experience, the general success rate for the taxpayer is about 41 percent. Second, including the various indicia of expertise, the effect of the ideology measure (the party of the appointing prime minister) became larger and weakly significant (with being heard by a judge appointed by a Liberal prime minister tending to reduce the success rate by 7 percentage points, to about 34 percent (significant at the 90 percent level). Third, the amount of time on the Tax Court was negative and statistically significant (at the 95 percent level), indicating that increased time on the court reduced the probability that a judge would vote in favour of the taxpayer. The effect was relatively small on a yearly basis (about -1 percent), but of course would add up as a judge became more experienced. Fourth, whether a judge had prior tax experience operated in the opposite direction and had no impact

47 Hwong, "An Exploration of Influences of Sociodemographic Characteristics," supra note 2, and Hwong, "A Quantitative Exploration of Judicial Decision Making," ibid.

48 We ran ordinary least squares (OLS) regressions even though the dependent variable was dichotomous, since we were also including interaction terms. We used dprobit to check the results. We have included the results of the OLS regressions in this article because the coefficients are easier to interpret. For a glossary of variable names, see appendix A. For these regressions, we clustered the votes by judge. 
TABLE 5 Politics, Experience, and Taxpayer Success at the Tax Court of Canada

\begin{tabular}{|c|c|c|c|}
\hline Variables & $\begin{array}{c}(1) \\
\text { TCC_Pro_Taxpayer }\end{array}$ & $\begin{array}{c}(2) \\
\text { TCC_Pro_Taxpayer }\end{array}$ & $\begin{array}{c}(3) \\
\text { TCC_Pro_Taxpayer }\end{array}$ \\
\hline TCCLiberalAppt & $\begin{array}{r}-0.0298 \\
(0.0405)\end{array}$ & $\begin{array}{r}-0.0690^{*} \\
(0.0401)\end{array}$ & $\begin{array}{r}-0.0500 \\
(0.0355)\end{array}$ \\
\hline Yrs_TCC_Exp & & $\begin{array}{c}-0.00699^{* *} \\
(0.00260)\end{array}$ & $\begin{array}{c}-0.00697^{* * *} \\
(0.00193)\end{array}$ \\
\hline TCC_Tax_Professional & & $\begin{array}{c}0.0351 \\
(0.0503)\end{array}$ & $\begin{array}{c}0.0232 \\
(0.0401)\end{array}$ \\
\hline TCC_Private_Practice & & $\begin{array}{r}0.107^{* *} \\
(0.0432)\end{array}$ & $\begin{array}{c}0.0729 \\
(0.0544)\end{array}$ \\
\hline TCC_Public_Sector & & $\begin{array}{l}0.0944^{* *} \\
(0.0438)\end{array}$ & $\begin{array}{r}0.0699^{*} \\
(0.0382)\end{array}$ \\
\hline TCC_Academic & & $\begin{array}{c}0.0481 \\
(0.0317)\end{array}$ & $\begin{array}{c}0.0402 \\
(0.0278)\end{array}$ \\
\hline TCCGender & & & $\begin{array}{c}0.0442 \\
(0.0492)\end{array}$ \\
\hline TP_Private_Corp & & & $\begin{array}{r}0.103^{* *} \\
(0.0377)\end{array}$ \\
\hline TP_Public_Corp & & & $\begin{array}{r}0.163^{* *} \\
(0.0623)\end{array}$ \\
\hline TP_Other & & & $\begin{array}{l}-0.112^{*} \\
(0.0548)\end{array}$ \\
\hline TCCLibPrivCorp & & & $\begin{array}{c}-0.0421 \\
(0.0511)\end{array}$ \\
\hline TCCLibPubCorp & & & $\begin{array}{c}-0.0956 \\
(0.120)\end{array}$ \\
\hline TCCLibPartyOther & & & $\begin{array}{l}0.148^{*} \\
(0.0747)\end{array}$ \\
\hline Rep_Counsel & & & $\begin{array}{l}0.116^{* * *} \\
(0.0270)\end{array}$ \\
\hline Rep_AgentOther & & & $\begin{array}{l}0.0550^{* *} \\
(0.0214)\end{array}$ \\
\hline General_Procedure & & & $\begin{array}{l}0.0683^{* *} \\
(0.0249)\end{array}$ \\
\hline Other_Procedure & & & $\begin{array}{c}0.0239 \\
(0.0284) \\
(0.0362)\end{array}$ \\
\hline Constant & $\begin{array}{l}0.504^{* * *} \\
(0.0192)\end{array}$ & $\begin{array}{l}0.412^{* * *} \\
(0.0621)\end{array}$ & $\begin{array}{l}0.380^{* * *} \\
(0.0663)\end{array}$ \\
\hline Mean of dependent variable & 0.49003 & 0.49003 & 0.49003 \\
\hline Observations & 3,411 & 3,411 & 3,411 \\
\hline$R^{2}$ & 0.001 & 0.014 & 0.051 \\
\hline
\end{tabular}

TCC $=$ Tax Court of Canada.

$\mathrm{TP}=$ taxpayer.

${ }^{* * *} p<0.01,{ }^{* *} p<0.05,{ }^{*} p<0.1$.

Note: Robust standard errors in parentheses. 
on the tendency to vote in favour of the taxpayer. Finally, both prior private- and public-sector experience tended to increase the probability of success of the taxpayer by about 10 percentage points (each significant at the 95 percent level) — that is, to about 51 percent. Prior public-sector experience may have been expected to act in the opposite direction-to increase the likelihood to sympathize with the government-yet in this analysis it has the opposite effect.

One of the difficulties is designing the analysis to pick up differences in judicial voting across types of cases. It cannot be as simple as the taxpayer versus the government because the lack of categorization of the parties ignores the potential sources of differences in preferences of Liberal and Conservative judges. For example, as noted above, Staudt et al. found a significant relationship between outcomes in tax cases and ideology of judges only for corporate tax cases (with liberal judges more likely than conservative judges to find for the government in such cases). ${ }^{49}$ They found no significant relationship between outcome and ideology in the pooled cases or in the regressions using only cases involving individual taxpayers.

We therefore ran the regressions controlling for various factors (table 5, column 3). First, we controlled for the type of taxpayer that was bringing the challenge- that is, whether the party was an individual, a private corporation, a public corporation, or another type of party (including a partnership, a charitable organization, an estate, or a government). The omitted category is an individual taxpayer..$^{50}$ Second, in order to determine whether there was a difference in voting for different parties across judges with different ideologies, we included interaction terms for the party of the appointing prime minister and the party bringing the application. Third, we controlled for procedural aspects of the case before the Tax Court, including the procedure followed (the informal procedure, the general procedure, or other procedure) and the nature of the representation of the party (self-representation, represented by counsel, represented by an agent, or other representation). The regressions omit self-representation and the informal procedure..$^{51}$

Figure 1 sets out the results of this regression in percentage change form-that is, by what percent does the factor change the taxpayer's probability of success relative to the base level of about 38 percent. The base level of success in this regression is for a decision involving an unrepresented individual following the informal procedure with the decision heard by a judge who was appointed by a Conservative prime minister and who had no prior Tax Court or tax experience.

49 Staudt et al., supra note 2.

50 Omitting a category allows the regression to use the omitted category as a baseline, so the results in this case are the change in chance of winning as compared with the taxpayer being an individual.

51 The "other procedure" category includes procedures other than informal or general, and mixed procedures, while "other representation" includes cases where no one appeared, where the counsel or agent was not specified, where there was mixed representation, or where the representation was unknown. This regression also controls for the province in which the case originated, as well as whether the hearing was completed in a single day or extended over two or more days. The coefficients for these controls are not shown. 


\section{FIGURE 1 Influence of Judicial Political Preference and Expertise on Taxpayer Success at the Tax Court of Canada}

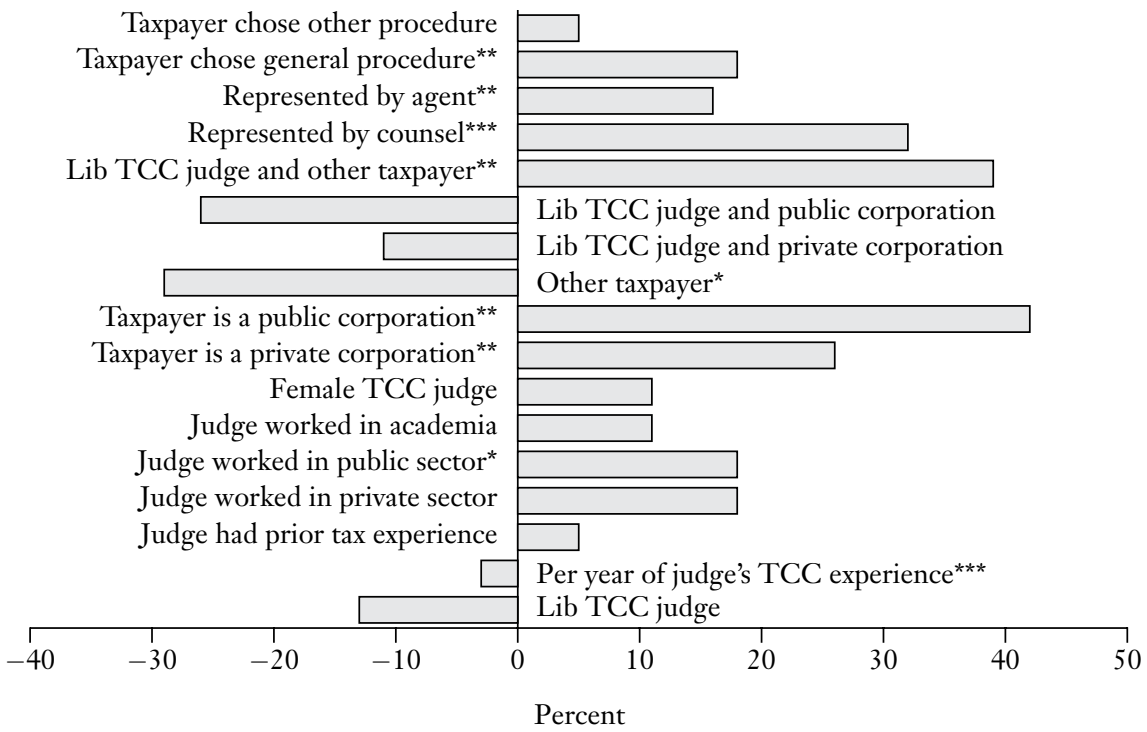

$\mathrm{Lib}=$ appointed by a Liberal prime minister.

TCC $=$ Tax Court of Canada.

${ }^{* * *} p<0.01,{ }^{* *} p<0.05,{ }^{*} p<0.1$.

Note: This figure shows the percentage change in probability of taxpayer success at the TCC relative to an unrepresented individual following the informal procedure before a Conservativeappointed judge with no prior TCC or tax experience.

First, while the coefficient for facing a judge appointed by a Liberal prime minister (Lib TCC judge) implies a reduction in the probability of success of about 13 percent, this difference is not statistically significant (that is, there is no statistically significant difference between Conservative appointees and Liberal appointees deciding individual taxpayer appeals). This result is consistent with the notion that the category of individual taxpayer is difficult to assess since it encompasses many different types of taxpayers.

Second, the only indicia of judicial experience that were statistically significant were years on the Tax Court and whether the judge had worked in the public sector. As noted previously, time on the Tax Court makes a judge less likely to find in favour of a taxpayer. For each year that the judge hearing the decision has served on the Tax Court, the taxpayer success rate is reduced by about 3 percent. Given that the average time on the Tax Court for the judges in our database is approximately 10 years, that would translate (all other things being equal) to a success rate of about 28 percent (recall that the base case success rate is about 38 percent). Having a judge with public-sector experience was correlated with an 18 percent increase in the probability of success (significant at the 90 percent level). 
Third, the increase in the success rate for a private corporation at the Tax Court was about 26 percent, while for a public corporation the increase in the success rate was about 42 percent (both of these differences are significant at the 95 percent level). The win rate of the other parties, on the other hand, was lower than for individuals (significant at the 90 percent level). Conservative judges are therefore more likely to find in favour of private and public corporations but less likely to find in favour of "other taxpayers" (such as governments, trusts, charities, and unions). The interaction terms (Lib TCC judge and private corporation; Lib TCC judge and public corporation; and Lib TCC judge and other taxpayer) indicate whether Liberal appointees vote significantly differently than Conservative appointees for these parties. While the values of these variables seem large, the relationship was statistically significant only for "other taxpayers." These results imply that Liberal-appointed judges do not vote significantly differently than Conservative judges where the taxpayer is either a private corporation or a public corporation. Both private and public corporations therefore have a greater likelihood of success than individual taxpayers regardless of the ideology of the Tax Court judge. Other taxpayers did, however, have a higher success rate under Liberal judges than under Conservative judges.

Fourth, representation of some form is correlated with a large (and statistically significant) boost in the success rate, with taxpayers represented by counsel enjoying about a 32 percent greater success rate and taxpayers represented by agents a 16 percent greater success rate than self-represented taxpayers. Similarly, use of the general procedure is correlated with an increased success rate of almost 18 percent, all other things being equal, compared with use of the informal procedure..$^{52}$ To find that there is a causal relationship between either the type of representation or the procedure and the outcome at the Tax Court, it is necessary to assume that the taxpayer does not choose the form of representation or procedure on the basis of the strength of the case-that is, that the (cheaper) self-representation or informal procedure is chosen only where there is a lower probability of success.

The other aspect of the Tax Court decisions that may be important is how judges deal with the seemingly most vulnerable or least powerful taxpayers. These taxpayers seem likely to be individuals who are unrepresented and use the informal procedure.

Figure 2 provides the results of an analysis examining whether there is a correlation between the ideological preferences of judges and whether vulnerable individuals are successful at the Tax Court, with the values showing differences in probabilities of success relative to voting by a Conservative-appointed judge..$^{53} \mathrm{~A}$ taxpayer other than

52 In this regression we also controlled for a number of other factors, such as the province in which the application was heard (with Ontario being the omitted province) and whether the hearing extended over multiple days. In these regressions, the only significant difference in voting across provinces was that taxpayers whose cases were heard in Quebec were 21 percent less likely to succeed than those in Ontario (significant at the 95 percent level).

53 As with the previous analyses, the dependent variable is the success of the party at the Tax Court. These results are from an OLS regression with clustering on the identity of the judge. 


\section{FIGURE 2 Probability of Success of Vulnerable Parties Under Different Tax Court Judges}

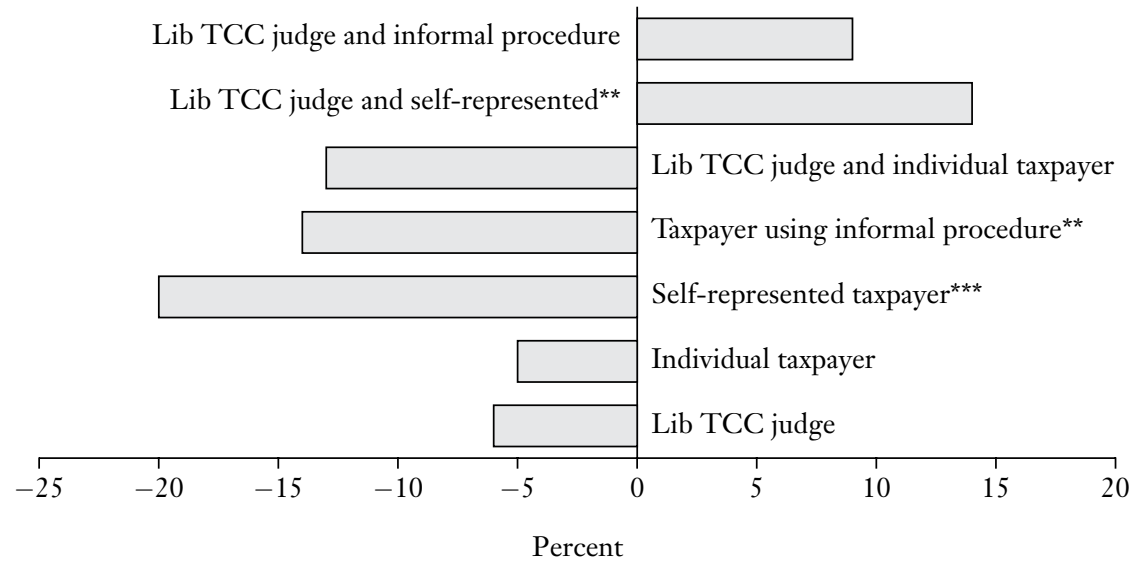

$\mathrm{Lib}=$ appointed by a Liberal prime minister.

TCC $=$ Tax Court of Canada.

${ }^{* * *} p<0.01,{ }^{* *} p<0.05,{ }^{*} p<0.1$.

Note: This figure shows the change in probability of taxpayer success at the TCC relative to a party who was not an individual, was represented, and chose the general procedure before a Conservative-appointed judge.

an individual, who is represented by counsel or an agent, and who uses the general procedure has a success rate of about 64 percent before a Conservative appointee (significant at the 99 percent level). While there appears to be a difference in how Conservative- and Liberal-appointed judges vote (with taxpayers having a lower success rate before Liberal appointees), the difference is not statistically significant. However, both self-representation and use of the informal procedure tend to be correlated with a significantly lower rate of success. Self-represented taxpayers have about a 20 percent lower success rate before a Conservative-appointed judge than a taxpayer who is represented by counsel or an agent (significant at the 99 percent level), while taxpayers using the informal process have a 14 percent lower success rate. As discussed above, a causal relationship between representation and procedure chosen and the success rate relies on the assumption that the ex ante probability of success did not drive the choice of representation or procedure. Figure 2 shows the results of including interaction terms to control for differences in how Liberal-appointed judges and Conservative-appointed judges respond to these factors. A Liberal-appointed judge is 14 percent more likely to vote in favour of a self-represented party than a Conservative-appointed judge (at the 95 percent level of significance), though such a difference means that a Liberal appointee is still slightly less likely to find in favour of a self-represented taxpayer compared to other taxpayers. The remaining 
interaction terms are not statistically significant, indicating that there is no difference in how Liberal and Conservative appointees vote in relation to whether the taxpayer is an individual or is using the informal procedure.

At the Tax Court, then, ideology does not appear to play a large role, though experience of the judge and the resources of the challenging party are important. There is in general no significant difference in how Liberal- and Conservative-appointed judges vote in Tax Court decisions, including in the case of vulnerable individuals. The main exception is that self-represented parties tend to have greater success in front of Liberal appointees than Conservative appointees (though they still do worse overall than represented parties). Corporations (both private and especially public) have a higher success rate than individuals at the Tax Court whether a Liberal or a Conservative appointee hears the case. Moreover, parties have a greater probability of success if they are represented (either by counsel or by an agent) or follow the general procedure. Judicial experience has an interesting impact on voting. Judges with more experience on the Tax Court tend to be less likely to find in favour of the taxpayer, while judges with prior public-sector experience tend to find in favour of the taxpayer.

\section{The Appeal Rate}

There are, then, patterns to outcomes at the Tax Court, including that corporations are more likely to succeed, as are those who use some form of representation and go through the general procedure. These factors are, of course, not exogenous to the success rate. It could be that corporations and those with some form of representation are less likely to bring forward weak cases and therefore are more likely to succeed. Given these success rates, however, a further question is what influences whether a particular decision is appealed. Are certain parties more likely to appeal than others? Do the characteristics of the judge who heard the appeal, such as his or her political preferences or experience, relate to the rate at which a decision is appealed? The rate of appeal could be viewed as a marker of the quality of the Tax Court decision.

In order to examine these issues, we ran a series of regressions in which the dependent variable was whether or not the decision was appealed to the Federal Court of Appeal. Figure 3 provides the results of this analysis, showing the differences in probabilities relative to an individual unrepresented taxpayer, with a single-day hearing in front of a Conservative-appointed judge, in terms of percentage change in the rate of success. The base appeal rate is 10 percent, which is for the case of a government win at the Tax Court against an individual taxpayer in front of a Conservative-appointed judge with no prior Tax Court or tax experience, where the taxpayer was self-represented and followed the informal procedure. Figure 3 shows that if the taxpayer succeeds at the Tax Court, there is an approximately 80 percent lower probability of an appeal (relative to the base rate of 10 percent) than if the government prevails at the Tax Court (significant at the 99 percent level); that is, the government is less likely to appeal its Tax Court losses than are taxpayers. 


\section{FIGURE 3 Influences on Likelihood of Appeal (Percentage Difference Relative to Base Case of a 10 Percent Rate of Appeal)}

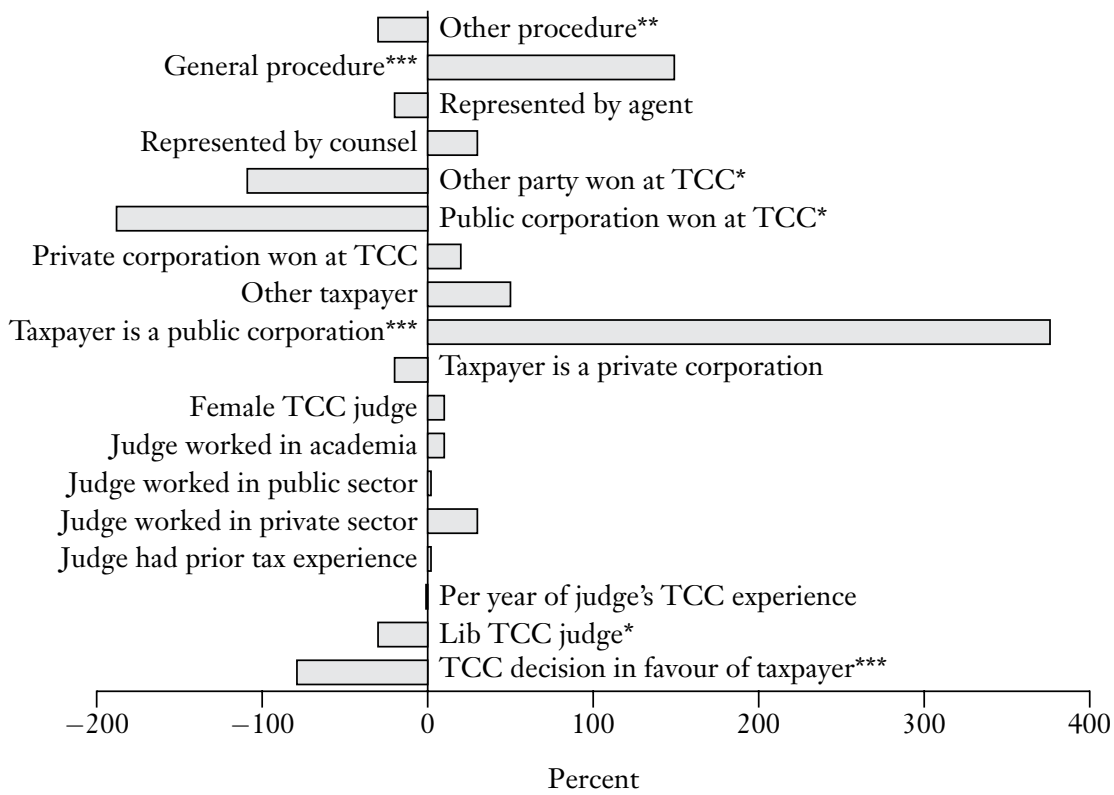

$\mathrm{Lib}=$ appointed by a Liberal prime minister.

TCC $=$ Tax Court of Canada.

${ }^{* * *} p<0.01,{ }^{* *} p<0.05,{ }^{*} p<0.1$.

Note: This figure shows the change in probability of an appeal of a TCC decision relative to an individual taxpayer who lost at the TCC, was unrepresented, and chose the informal procedure with a single-day hearing in Ontario before a judge not meeting any of the criteria in the figure.

Further, there is no different rate of appeal for private corporations than for individuals, but a public corporation is almost four times more likely to appeal a loss than is an individual taxpayer (significant at the 99 percent level). Further, if the public corporation won at the Tax Court, there was a lower probability of appeal (by the government) than if it lost (significant at the 90 percent level), but the government was more likely to appeal a loss to a public corporation than to an individual taxpayer. These results mean that in any case involving a public corporation versus the government, there is a high rate of appeal whatever the outcome at the Tax Court. Another interesting result from the regression is that there is a substantially higher rate of appeal (about 150 percent) from Tax Court decisions that went through the general procedure compared to the informal procedure (significant at the 99 percent level) and a lower rate of appeal ( -30 percent) for decisions that went through other procedures (significant at the 99 percent level). These appeal rates seem unlikely to be completely exogenous (and, again, are relative to the base rate of 
10 percent). An application may have gone through the general procedure because the stakes were higher or the likelihood of success was higher, in which case the probability of an appeal would be higher.

Appeal rates may also be influenced by the quality of the Tax Court decision. It may be, for example, that decisions by judges with tax expertise are less likely to be appealed because they may be of higher quality. In the US context, Wright and Diveley attempted to assess whether having an expert decision maker in antitrust litigation improves the quality of the decision..$^{54}$ They examined decisions between 1976 and 2010 in which an administrative-law judge decided a substantive antitrust claim, along with reported decisions between 1977 and 2007 of article III federal district court judges on substantive antitrust claims. The authors' aim was to examine whether the Federal Trade Commission with its claim to expertise was superior in its decision making to generalist judges. They examined the likelihood of appeal as their primary indicator of the quality of the underlying decision on the assumption that, all other things being equal, an appeal means that at least one of the parties believes that it can convince a higher court that the original decision contained a reversible error. Wright and Diveley also examined reversal rates (an issue that we address in the next section). They find that, contrary to the hypothesis that a specialist's decision should be appealed at a lower rate, the specialist commission decisions were both appealed and reversed at a higher rate than the generalist court decisions.

Figure 3 layers on judge characteristics to determine whether there may be a connection of either ideology or expertise to rates of appeal. There is no significant connection between our markers of experience (years on the Tax Court bench and prior tax experience) and the rate at which the decisions are appealed, nor is the appeal rate related to the judge's experience prior to joining the Tax Court. Decisions of Liberal-appointed judges are, however, less likely to be appealed (30 percent less likely, relative to the base rate of 10 percent) than are decisions of Conservativeappointed judges (significant at the 90 percent level). Such a finding could relate to either the case mix of Liberal judges or a difference in other quality factors in favour of Liberal-appointed judges not picked up by years on the bench or prior tax experience..$^{55}$

Thus, the government is less likely to appeal losses at the Tax Court than are taxpayers. In terms of taxpayers, public corporations are much more likely to be involved in an appeal compared to individuals or private corporations. Further, there is only a slight connection between judge characteristics and the rate of appeal, relating mainly to the ideology of the judge rather than to direct markers of tax expertise.

54 Joshua D. Wright and Angela Diveley, "Do Expert Agencies Outperform Generalist Judges? Some Preliminary Evidence from the Federal Trade Commission" (2013) 1:1 Fournal of Antitrust Enforcement 82-103.

55 These regressions included controls for province of origin of the case and length of hearing, which were not reported. 


\section{The Affirmation Rate}

Another possible marker of the quality of the Tax Court decision is whether it was affirmed on appeal to the Federal Court of Appeal. All other things being equal, one would expect poorer-quality Tax Court decisions to be affirmed less often (that is, reversed or varied more frequently). There may, however, be other influences on affirmation, such as the quality or politics of the judges at the Federal Court of Appeal. We therefore attempted to assess the factors influencing the affirmation rate of Tax Court decisions appealed to the Federal Court of Appeal.

First, consider whether particular Court of Appeal judges are more or less likely to affirm a Tax Court decision. Figure 4 shows how different factors affect this probability. In the regressions that are the basis for this figure, the dependent variable was whether the particular judge reversed the Tax Court decision (that is, we are working with judge votes, not the outcomes of Federal Court of Appeal panels). ${ }^{56}$ In general, almost 80 percent of appeals to the Court of Appeal were affirmed where the taxpayer was an unrepresented individual taxpayer and the government won at the Tax Court. ${ }^{57}$ If the Tax Court decision was in favour of the taxpayer and the taxpayer was an individual, the affirmation rate at the Federal Court of Appeal was decreased by more than 40 percent relative to when the government succeeded at the Tax Court (significant at the 99 percent level), controlling for a range of factors relating to the type of party, the nature of the procedures followed, and the characteristics of the Tax Court and Appeal Court judges.

However, as seen in figure 4, when the affirmation rate is broken down further in terms of parties, the Court of Appeal judges are even more likely to affirm Tax Court judgments in favour of corporations. In this case, if a private corporation won at the Tax Court and the government appealed, the affirmation rate was only slightly (about 8 percent) lower than the rate when the government won at the Tax Court. A public corporation that won at the Tax Court had an even higher affirmation rate compared to when the government won (about 6 percent higher). There is no statistically significant difference in the affirmation rate across different types of taxpayers where the taxpayer loses at the Tax Court. It appears, then, that the Federal Court of Appeal tends to affirm more often in the case of government success at the Tax Court level, except that where the taxpayer is a public corporation, the opposite is true, and where the taxpayer is a private corporation, the affirmation rate for the taxpayer is much more similar to the affirmation rate for the government.

The other area in which there was a statistically significant difference across appeals related to representation. Tax Court decisions where the taxpayer was represented were less likely to be affirmed than decisions for self-represented parties.

56 An OLS regression was used for figure 6. To check the results, we also ran a probit regression. We present the OLS results because of the potential difficulties with interpreting the interaction terms in probit. For the regressions in this part of the article, we clustered the results on the case, given that appeals are heard in panels.

57 The constant in the regression was 0.778 , significant at the 99 percent level. 


\section{FIGURE 4 Influences on Affirmation Rates at the Federal Court of Appeal}

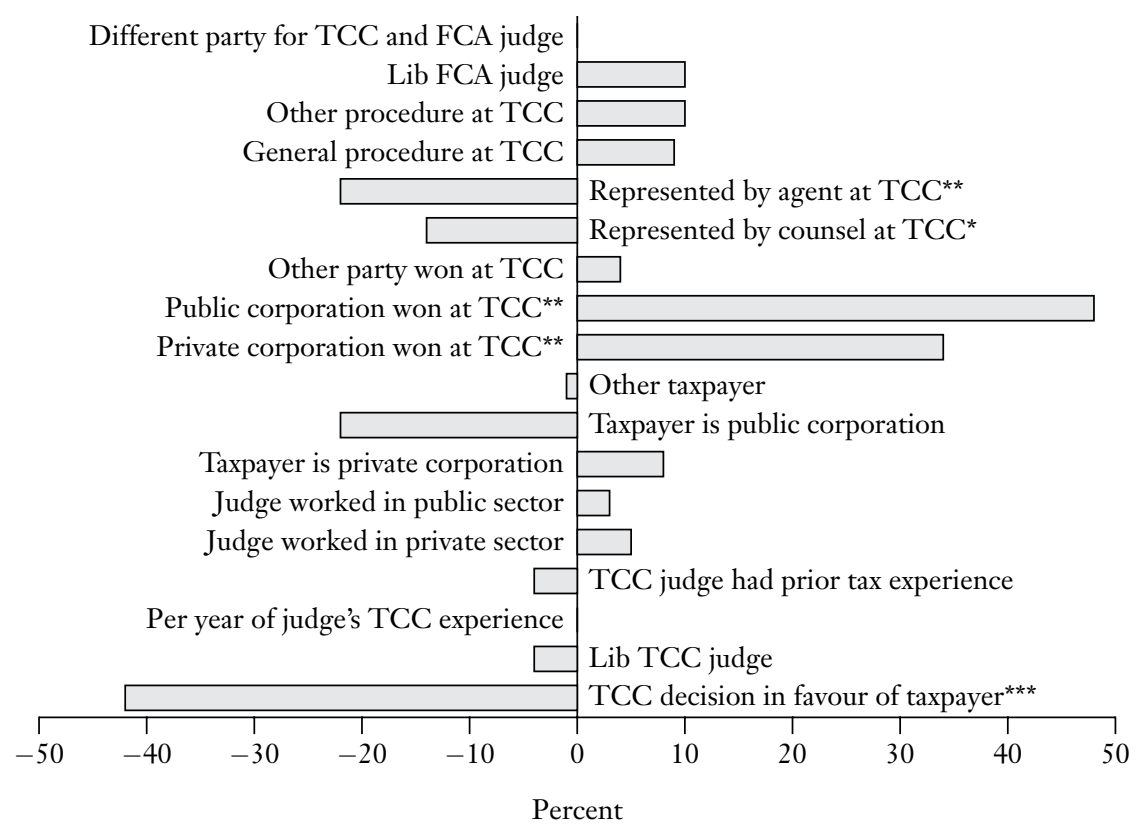

$\mathrm{FCA}=$ Federal Court of Appeal.

$\mathrm{Lib}=$ appointed by a Liberal prime minister.

TCC $=$ Tax Court of Canada.

${ }^{* * *} p<0.01,{ }^{* *} p<0.05,{ }^{*} p<0.1$.

Note: This figure shows the change in probability of affirmation of a TCC decision on appeal to the FCA relative to an individual taxpayer who lost at the TCC, was unrepresented, and chose the informal procedure, and whose case was heard by a Conservative-appointed TCC judge without prior tax experience.

Since represented parties tended to have greater success at the Tax Court level, the lower affirmation rate may mean that the Tax Court judges were overly influenced by representation of taxpayers. It is interesting to note that there was no statistically significant difference in the affirmation rate related to the taxpayer's use of the general or the informal procedure at the Tax Court (even though that was an important factor in the outcome at the Tax Court level and in terms of whether a decision was appealed).

In terms of the quality of the Tax Court decision, as we noted in the prior section, one indication of the quality of the judging could be the affirmation rate on appeal. Judges with greater experience would be expected to render higher-quality decisions and therefore have a higher affirmation rate in general. However, neither political preference nor expertise (time on the Tax Court or prior tax experience) of the Tax Court judge was a significant factor in the affirmation rate. 
Additional factors that may influence the affirmation rate are the characteristics of the Federal Court of Appeal judge deciding the appeal. Figure 4 includes political characteristics of the Federal Court of Appeal judges. As noted previously, in the United States there is some connection between the politics of the judge and his or her rate of affirmation of decisions (although these studies are of direct appeals from government decisions, not appeals from a lower court). There is no significant difference in the affirmation rates of Federal Court of Appeal judges appointed by Liberal as opposed to Conservative prime ministers.

However, it may not simply be the political preferences of the Federal Court of Appeal judges that matter, but rather differences in the political preferences of the Federal Court of Appeal judge voting to affirm or not and the Tax Court judge who heard the initial decision. It would be natural to expect, for example, that a Liberalappointed Federal Court of Appeal judge may be more likely to affirm a decision by a Liberal-appointed Tax Court judge, if their political preferences align. However, we found no effect of such differences in political preferences when examining votes of individual judges, as outlined in figure 4. (As noted below, we did find a difference when considering case outcomes - that is, whether the panel voted to affirm - as opposed to individual judge votes.) Where the judges were appointed by prime ministers of different political parties, there was no statistically significant difference in the affirmation rate compared to judges appointed by prime ministers of the same party.

Finally, panel effects may also influence Federal Court of Appeal judges. There is evidence from studies on the US courts of appeal that judges will vote differently depending on the identity and attributes of other judges on the same panel. Democratic appointees have higher rates of voting in a liberal direction if they are on panels with other Democratic appointees than if there are conservative appointees on the panel. ${ }^{58}$ These differences may be due to differences in deliberation across different panel compositions, a dislike of dissenting, "whistleblowing" by judges of different ideological preferences, or a form of "group polarization." 59 We tested whether the composition of the Federal Court of Appeal panel influenced a judge's probability of affirming a Tax Court decision. We ran regressions in which an individual judge's vote to affirm or not was the dependent variable, independent variables included dummy variables for different panel compositions, and the baseline case was an all-Liberal appointee panel. ${ }^{60}$ Figure 5 provides the results of this regression

58 See, for example, Cass R. Sunstein, David Schkade, Lisa M. Ellman, and Andres Sawicki, Are Judges Political? An Empirical Analysis of the Federal Fudiciary (Washington, DC: Brookings Institution, 2006).

59 See Joshua B. Fischman, "Interpreting Circuit Court Voting Patterns: A 'Social Interactions' Framework," Fournal of Law, Economics, and Organization (forthcoming), for a discussion of various explanations for differences in voting across different panel compositions. Examining a range of areas of law, Fischman finds that the most important influence is a strong norm of consensus.

60 While OLS regressions have some shortcomings, these difficulties are not problematic where the regressors are discrete or bounded (Fischman, ibid.). 
(along with a variety of other controls). None of the differences in affirmation rates for different panel compositions were statistically significant. ${ }^{61}$

However, the votes at the individual level could be masking a combined effect of panel influences. We therefore ran the regressions using case outcomes (affirmed versus reversed or varied) as opposed to individual judge votes as the dependent variable (that is, whether the outcome of the appeal was to affirm the Tax Court decision). In order to assess panel effects, as independent variables we included the percentage of the panel that were Conservative appointees (with the base case being an all-Liberal panel) along with looking at the interaction between the proportion of Conservative appointees on the panel and whether the Tax Court judge found in favour of the taxpayer (see figure 6). Some interesting things emerge from these regressions.

First, in contrast to the prior regressions, the affirmation rate was lower where the Tax Court judge was a Liberal appointee rather than a Conservative appointee (17 percent lower, significant at the 95 percent level).

Second, if the Tax Court decision was by a Conservative appointee, then regardless whether the judgment of the Tax Court was in favour of or against the taxpayer, an appeal from the decision had an equal likelihood of being dismissed whether the Federal Court of Appeal panel was made up of three Liberal judges or three Conservative judges (that is, the interaction term for the percentage of Conservative appointees on the panel was not significant). If a Conservative Tax Court judge decided in favour of the government and the decision was appealed to three Liberal Court of Appeal judges, the likelihood of affirmation was about 89 percent. If the same decision was appealed to three Conservative Court of Appeal judges, the affirmation rate was lower by about 7 percent, but the difference was not statistically significant. On the other hand, if a Conservative Tax Court judge decided in favour of the taxpayer and the decision was appealed to three Liberal Court of Appeal judges, the likelihood of affirmation dropped by 25 percent (significant at the 95 percent level). Largely the same pattern held in reverse if the Tax Court judge was a Liberal appointee. Where a Liberal Tax Court judge decided in favour of the taxpayer and the decision was appealed, the affirmation rates were similar for three Conservative Court of Appeal judges (49 percent) and three Liberal judges (53 percent). On the other hand, where a Liberal Tax Court judge decided in favour of the government and the decision was appealed to three Conservative Court of Appeal judges, the likelihood of affirmation was predicted to be 100 percent. If the same decision was appealed to three Liberal Court of Appeal judges, the likelihood of affirmation was lower at 75 percent. Thus, no matter which party succeeded before

61 Following Fischman, ibid., we also attempted to determine whether panel effects existed using not dummies for different types of panels but an independent variable taking values of 0,1 , or 2 depending on the number of other Liberal judges on the panel, along with an interaction term between whether the Federal Court of Appeal judge was a Liberal appointee and this new variable on the number of other Liberal appointees. The coefficients and their levels of significance were all very similar to the regression in appendix table B5-that is, we found no statistically significant panel effects when we examined judge votes. 


\section{FIGURE 5 Influences on Affirmation Rates at the Federal Court of Appeal (Panel Effects)}

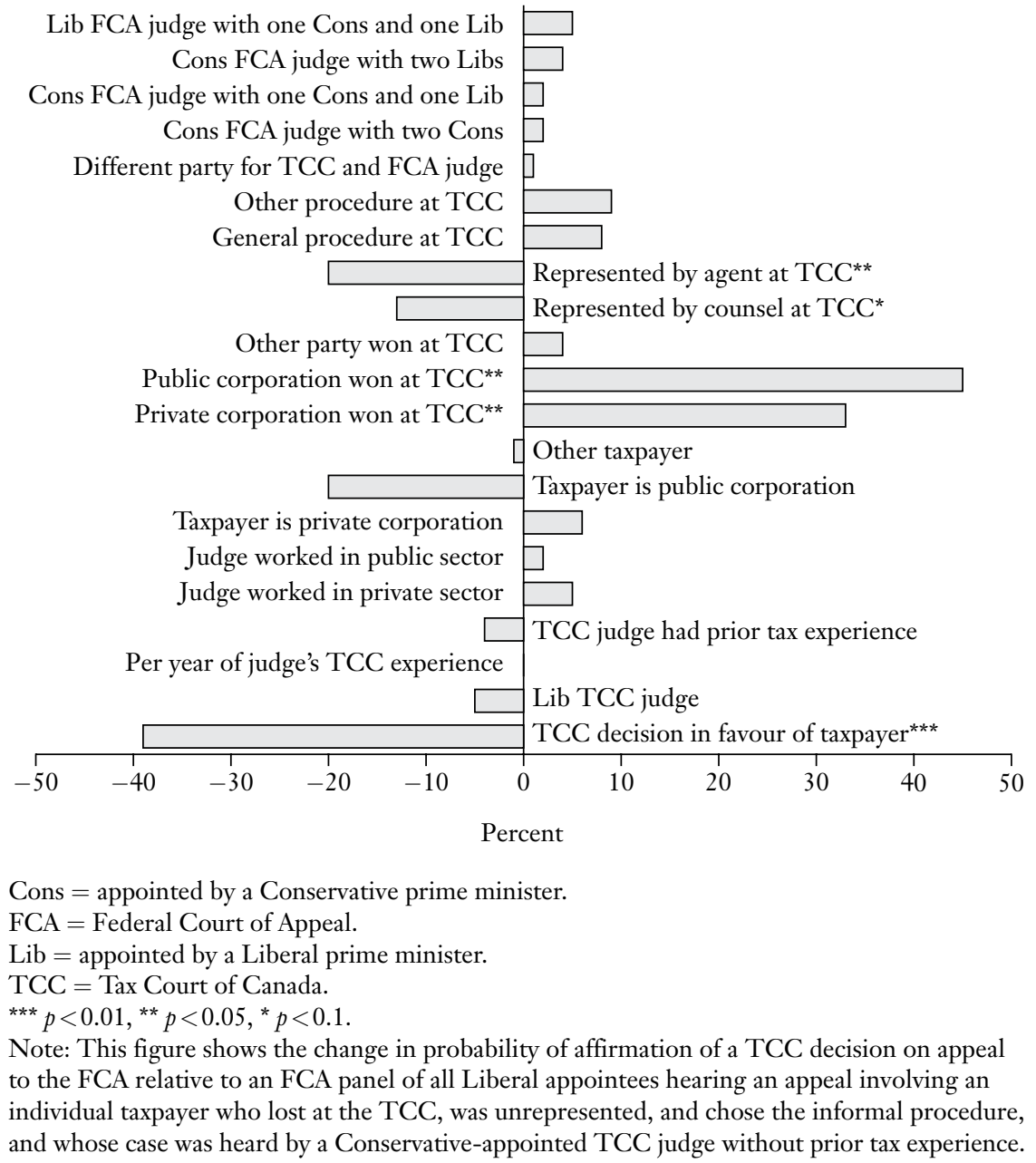

a Liberal Tax Court judge, the judgment fared better on appeal if the Court of Appeal panel was made up entirely of Liberals rather than all Conservatives.

It is not clear what is driving these results. One possibility is that judges may be sensitive to the potential for an appearance of political or partisan bias, and so may be more cautious about voting to reverse a judgment of a Tax Court judge with different political ties. Judges may not have such qualms about reversing or varying the judgment of a lower-court judge with the same political preferences. It is possible that the fact of having been appointed by a prime minister from the same political party gives an Appeal Court judge implicit licence to hear the appeal on the merits, and to be seen as having done so, whereas when there are political differences, deciding 


\title{
FIGURE 6 Influences on Affirmation Rates-Panel Effects Using Case Outcomes
}

\author{
Lib TCC judge and percent Cons panel*** \\ Taxpayer won before Lib judge \\ Other procedure at TCC \\ General procedure at TCC

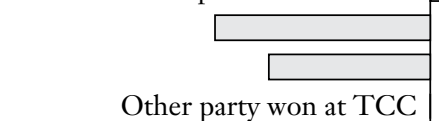 \\ Taxpayer won and percent Cons panel ${ }^{*}$ \\ FCA panel percent Cons \\ Cons $=$ appointed by a Conservative prime minister. \\ $\mathrm{FCA}=$ Federal Court of Appeal. \\ $\mathrm{Lib}=$ appointed by a Liberal prime minister. \\ TCC $=$ Tax Court of Canada. \\ ${ }^{* * *} p<0.01,{ }^{* *} p<0.05,{ }^{*} p<0.1$. \\ Note: This figure shows the change in probability of affirmation of a TCC decision on appeal \\ to the FCA using case outcomes (that is, outcomes on appeal rather than individual judge \\ votes). The differences are relative to an FCA panel of all Liberal appointees hearing an appeal \\ involving an individual taxpayer who lost at the TCC, was unrepresented, and chose the \\ informal procedure, and whose case was heard by a Conservative-appointed TCC judge \\ without prior tax experience.
}

to reverse the Tax Court judge might be perceived by some as being politically motivated - a perception that Canadian appellate judges might understandably prefer to avoid.

Another way to frame the same phenomenon would be to posit that Court of Appeal panels made up entirely of judges of the same party as the Tax Court judge may be particularly sensitive to wanting to avoid potential ideological or results-motivated decision making by the Tax Court judge. Thus, if one believes that Conservative appointees to the Tax Court are more likely to be disposed to finding in favour of the taxpayer, on the basis of personal policy preferences, and if one cares about the perception of fairness of Tax Court judging and want it to be perceived as non-biased 
and fair, then one might well conceive of a Court of Appeal panel of all Conservative judges scrutinizing a pro-taxpayer judgment on appeal more carefully than a progovernment decision. Indeed, this is what the analysis suggests, with a 20 percent affirmation rate by an all-Conservative panel for pro-taxpayer decisions, compared to a 67 percent rate for pro-government decisions. Similarly, if one believes that Liberal Tax Court judges are more likely to be pro-government, then an all-Liberal Court of Appeal panel might visit more scrutiny on a pro-government Tax Court Liberal decision than a pro-taxpayer Tax Court Liberal decision. Again, this is borne out by the analysis, with a 53 percent affirmation rate for pro-government decisions and a 75 percent affirmation rate for pro-taxpayer decisions. This seems like a plausible explanation, not least because a reversal by a panel made up entirely of judges of the opposite party might well be accused of political decision making, even in the case of reversing a Tax Court judge that appears to be engaged in the same activity. In this case, it is safer merely to affirm, in order to avoid generating the possibility of being accused of precisely what one might otherwise be trying to correct for at the Tax Court level. These findings do not appear to have been replicated anywhere else in the judicial decision-making literature in Canada or elsewhere, and we find them surprising. They certainly merit further investigation.

\section{JUDGING THE TAXMAN}

There are a few conclusions that can be drawn from the foregoing analysis:

1. Policy preferences appear to matter in some circumstances in judging at the Tax Court, but the size of the effect is not strong, and expertise matters only slightly more.

2. Resources matter-a lot.

3. There are dynamics relating to affirmation of appeals that are difficult to explain, although a desire to avoid the apprehension of bias is possible.

First, there is robust evidence that policy preferences matter in the sense that there are measurable and statistically significant differences, but the size of the differences means that they are not likely to matter very much as a practical consideration. Liberal appointees are only slightly more likely to favour the government than are Conservative appointees. Most of the difference relates to those who may be the most vulnerable, the self-represented. Conservative appointees are 13 percent less likely to find in favour of a self-represented taxpayer than a taxpayer represented by counsel, while Liberal appointees are 9 percent more likely to find in favour of the self-represented taxpayer over the represented. This result is consistent with the literature, where it is frequently found that there is no effect, or only a weak effect, of party affiliations with voting patterns. Staudt et al. find no correlation between political preference and outcome in the case of an individual taxpayer, ${ }^{62}$ while Hwong

62 Staudt et al., supra note 2. 
finds a correlation at the Tax Court of Canada, but not at the Supreme Court. ${ }^{63}$ The results of our analysis mirror those of Hwong when only a few variables are considered as political preference is a factor, and then fall more in line with the work of Staudt et al. when more variables are considered. Our data show that at the Tax Court, judges with prior tax experience were more likely to vote for taxpayers, while time on the bench made judges progressively less likely to vote for taxpayers. Similarly, in the US context, Schneider has found that tenure on the court is associated with a greater probability of ruling for the government rather than the taxpayer. ${ }^{64}$ Interestingly, in a later article, Schneider affirms this association for judges in general, but finds that female judges tend to decide for the taxpayer rather than the government as time on the court increases. ${ }^{65}$ One possible extension of our own study would be to see if the same trend of male and female judges diverging in their preferences as tenure increases applies to Canada as well as the United States. We have found that the expertise of Tax Court judges made no real difference for either the decision to appeal or the outcome of the appeal. This article and Schneider's earlier work both find that female judges are more likely to rule in favour of the taxpayer than are their male counterparts, although Schneider's work fell just short of statistical significance. 66

Second, the analysis consistently shows that certain features are predictive of outcomes-representation, party type, and appeal choices. With respect to representation, self-represented litigants fare worse than taxpayers who are represented by tax agents, and taxpayers who are represented by agents fare worse than taxpayers who are represented by counsel. With respect to taxpayer types, individual taxpayers are consistently less successful than private corporations, and private corporations are consistently less successful than public corporations. With respect to appeal choices, the government is more selective about the cases that it appeals and is generally more successful than taxpayers, with the exception of public corporations.

Finally, we found that where the Tax Court judge and the judges on the Federal Court of Appeal panel were appointed by prime ministers of different political parties, as a general matter the Federal Court of Appeal was more (not less) likely to vote to affirm the Tax Court decision than in cases where the Court of Appeal judge and the Tax Court judge were appointed by a prime minister of the same party. It is not clear what is driving this result. One possibility is that judges may not want to appear to be politicized or partisan, and so may be more cautious about voting to reverse a decision of a Tax Court judge with different political ties. These findings do not appear to have been replicated anywhere else in the judicial decision-making literature in Canada or elsewhere, and we find them surprising. They certainly merit further investigation.

63 Hwong, "A Quantitative Exploration of Judicial Decision Making," supra note 2.

64 Schneider, "Assessing and Predicting Who Wins Federal Tax Trial Decisions," supra note 16.

65 Schneider, supra note 3.

66 Schneider, "Assessing and Predicting Who Wins Federal Tax Trial Decisions," supra note 16, at 500. Schneider finds an 89 percent significance level. 


\section{APPENDIX A GLOSSARY OF VARIABLES}

\section{TABLE A1 Glossary of Variables}

\begin{tabular}{|c|c|}
\hline Variable & Description \\
\hline Different_Party & FCA judge and TCC judge appointed by different parties \\
\hline $\begin{array}{l}\text { FCA_Cons_Majority } \\
\text { _with_Liberal }\end{array}$ & $\begin{array}{l}\text { FCA judge was one of exactly two Conservative appointees on } \\
\text { the panel }\end{array}$ \\
\hline $\begin{array}{l}\text { FCA_Cons_on_Three } \\
\text { _Conservative_Panel }\end{array}$ & FCA judge is a Conservative on an all-Conservative panel \\
\hline FCA_Judge_Lib & FCA judge was appointed by a Liberal prime minister \\
\hline $\begin{array}{l}\text { FCA_Liberal_Majority } \\
\text { _with_Conservative }\end{array}$ & $\begin{array}{l}\text { FCA judge was one of exactly two Liberal appointees on the } \\
\text { panel }\end{array}$ \\
\hline FCA_Lone_Conservative & FCA judge is only Conservative appointee on panel \\
\hline $\begin{array}{l}\text { FCA_Panel_Percentage } \\
\text { _Conservative }\end{array}$ & Fraction of FCA panel who are Conservative appointees \\
\hline General_Procedure & Taxpayer followed general procedure \\
\hline Informal_Procedure & Taxpayer followed informal procedure \\
\hline MultiDayHearing & The TCC hearing occurred over more than one day \\
\hline Other_Procedure & $\begin{array}{l}\text { Taxpayer followed procedure other than general or informal at } \\
\text { TCC }\end{array}$ \\
\hline OtherProvTerr & Appeal not in Ontario or above listed province \\
\hline ProTP_PercentCon & $\begin{array}{l}\text { Interaction of TCC_Pro_Taxpayer and FCA_Panel } \\
\text { _Percentage_Conservative }\end{array}$ \\
\hline ProTP_TCCJudgeLib & Interaction of TCC_Pro_Taxpayer and TCCLiberalAppt \\
\hline Prov_Alberta & Appeal in Alberta \\
\hline Prov_BC & Appeal in British Columbia \\
\hline Prov_Man & Appeal in Manitoba \\
\hline Prov_NB & Appeal in New Brunswick \\
\hline Prov_Quebec & Appeal in Quebec \\
\hline Prov_Sask & Appeal in Saskatchewan \\
\hline Rep_AgentOther & Taxpayer represented by non-counsel agent \\
\hline Rep_Counsel & Taxpayer represented by counsel \\
\hline Rep_Self & Taxpayer self-represented \\
\hline TCC_Academic & TCC judge was once an academic \\
\hline TCC_General_Procedure & Taxpayer followed general procedure at TCC \\
\hline TCC_Private_Practice & $\begin{array}{l}\text { TCC judge had private-practice work experience prior to } \\
\text { appointment }\end{array}$ \\
\hline TCC_Pro_Taxpayer & TCC decision in favour of the taxpayer \\
\hline TCC_Public_Sector & $\begin{array}{l}\text { TCC judge had public-sector work experience prior to } \\
\text { appointment }\end{array}$ \\
\hline TCC_Rep_AgentOther & Taxpayer represented by non-counsel agent at TCC \\
\hline
\end{tabular}

(Table A1 is concluded on the next page.) 
TABLE A1 Concluded

\begin{tabular}{ll}
\hline Variable & Description \\
\hline TCC_Rep_Counsel & Taxpayer represented by counsel at TCC \\
TCC_Tax_Professional & $\begin{array}{l}\text { TCC judge had professional tax experience prior to } \\
\text { appointment }\end{array}$ \\
TCCGender & Female TCC judge \\
TCCLib_FCA_Panel & Interaction of TCCLiberalAppt and FCA_Panel_Percentage \\
_Percentage_Conservative & -Conservative \\
TCCLiberalAppt & TCC judge appointed by Liberal prime minister \\
TCCLibIndividual & Interaction of TP_Individual and TCCLiberalAppt \\
TCCLibInformal & Interaction of Informal_Procedure and TCCLiberalAppt \\
TCCLibPartyOther & Interaction of TP_Other and TCCLiberalAppt \\
TCCLibPrivCorp & Interaction of TP_Private_Corp and TCCLiberalAppt \\
TCCLibPubCorp & Interaction of TP_Public_Corp and TCCLiberalAppt \\
TCCLibRepSelf & Interaction of Rep_Self and TCCLiberalAppt \\
TP_Individual & Taxpayer is an individual \\
TP_Other & Taxpayer is not a public/private corporation nor an individual \\
TP_Private_Corp & Taxpayer is a private corporation \\
TP_Public_Corp & Taxpayer is a public corporation \\
WinOtherParty & Interaction of TP_Other and TCC_Pro_Taxpayer \\
WinPrivCorp & Interaction of TP_Private_Corp and TCC_Pro_Taxpayer \\
WinPubCorp & Interaction of TP_Public_Corp and TCC_Pro_Taxpayer \\
Yrs_TCC_Exp & Number of years judge has spent on TCC \\
\hline
\end{tabular}

FCA $=$ Federal Court of Appeal.

$\mathrm{TCC}=$ Tax Court of Canada.

$\mathrm{TP}=$ taxpayer. 


\section{APPENDIX B REGRESSION TABLES}

\section{TABLE B1 Political Preference and Outcomes at Tax Court of Canada}

(1)

\begin{tabular}{|c|c|c|c|}
\hline Variables & TCC_Pro_Taxpayer & TCC_Pro_Taxpayer & TCC_Pro_Taxpayer \\
\hline TCCLiberalAppt & $\begin{array}{c}-0.0298 \\
(0.0405)\end{array}$ & $\begin{array}{r}-0.0690^{*} \\
(0.0401)\end{array}$ & $\begin{array}{c}-0.0500 \\
(0.0355)\end{array}$ \\
\hline Yrs_TCC_Exp & & $\begin{array}{c}-0.00699^{* *} \\
(0.00260)\end{array}$ & $\begin{array}{c}-0.00697^{* * *} \\
(0.00193)\end{array}$ \\
\hline TCC_Tax_Professional & & $\begin{array}{c}0.0351 \\
(0.0503)\end{array}$ & $\begin{array}{c}0.0232 \\
(0.0401)\end{array}$ \\
\hline TCC_Private_Practice & & $\begin{array}{c}0.107^{* *} \\
(0.0432)\end{array}$ & $\begin{array}{c}0.0729 \\
(0.0544)\end{array}$ \\
\hline TCC_Public_Sector & & $\begin{array}{l}0.0944^{* *} \\
(0.0438)\end{array}$ & $\begin{array}{r}0.0699^{*} \\
(0.0382)\end{array}$ \\
\hline TCC_Academic & & $\begin{array}{c}0.0481 \\
(0.0317)\end{array}$ & $\begin{array}{c}0.0402 \\
(0.0278)\end{array}$ \\
\hline TCCGender & & & $\begin{array}{c}0.0442 \\
(0.0492)\end{array}$ \\
\hline TP_Private_Corp & & & $\begin{array}{c}0.103^{* *} \\
(0.0377)\end{array}$ \\
\hline TP_Public_Corp & & & $\begin{array}{r}0.163^{* *} \\
(0.0623)\end{array}$ \\
\hline TP_Other & & & $\begin{array}{c}-0.112^{*} \\
(0.0548)\end{array}$ \\
\hline TCCLibPrivCorp & & & $\begin{array}{c}-0.0421 \\
(0.0511)\end{array}$ \\
\hline TCCLibPubCorp & & & $\begin{array}{c}-0.0956 \\
(0.120)\end{array}$ \\
\hline TCCLibPartyOther & & & $\begin{array}{c}0.148^{*} \\
(0.0747)\end{array}$ \\
\hline Rep_Counsel & & & $\begin{array}{l}0.116^{* * *} \\
(0.0270)\end{array}$ \\
\hline Rep_AgentOther & & & $\begin{array}{l}0.0550^{* *} \\
(0.0214)\end{array}$ \\
\hline General_Procedure & & & $\begin{array}{l}0.0683^{* *} \\
(0.0249)\end{array}$ \\
\hline Other_Procedure & & & $\begin{array}{c}0.0239 \\
(0.0284)\end{array}$ \\
\hline Prov_Quebec & & & $\begin{array}{c}-0.0745^{* *} \\
(0.0349)\end{array}$ \\
\hline Prov_BC & & & $\begin{array}{r}-0.0325 \\
(0.0335)\end{array}$ \\
\hline Prov_Alberta & & & $\begin{array}{c}0.00973 \\
(0.0405)\end{array}$ \\
\hline
\end{tabular}


TABLE B1 Concluded
(1)
(2)
(3)

\begin{tabular}{|c|c|c|c|}
\hline Variables & TCC_Pro_Taxpayer & TCC_Pro_Taxpayer & TCC_Pro_Taxpayer \\
\hline Prov_Sask & & & $\begin{array}{c}0.0648 \\
(0.0563)\end{array}$ \\
\hline Prov_Man & & & $\begin{array}{c}-0.00804 \\
(0.0568)\end{array}$ \\
\hline Prov_NB & & & $\begin{array}{r}-0.0707 \\
(0.0485)\end{array}$ \\
\hline OtherProvTerr & & & $\begin{array}{c}0.0423 \\
(0.0505)\end{array}$ \\
\hline MultiDayHearing & & & $\begin{array}{c}0.0215 \\
(0.0362)\end{array}$ \\
\hline Constant & $\begin{array}{c}0.504^{* * *} \\
(0.0192)\end{array}$ & $\begin{array}{c}0.412^{\text {*** }} \\
(0.0621)\end{array}$ & $\begin{array}{c}0.380^{* * *} \\
(0.0663)\end{array}$ \\
\hline Observations & 3,411 & 3,411 & 3,411 \\
\hline$R^{2}$ & 0.001 & 0.014 & 0.051 \\
\hline
\end{tabular}

${ }^{* * *} p<0.01,{ }^{* *} p<0.05,{ }^{*} p<0.1$.

Note: Robust standard errors in parentheses.

\section{TABLE B2 Success of Vulnerable Individuals at Tax Court of Canada}

\begin{tabular}{lc} 
Variables & TCC_Pro_Taxpayer \\
\hline TCCLiberalAppt & -0.0357 \\
& $(0.0579)$ \\
TP_Individual & -0.0313 \\
& $(0.0407)$ \\
Rep_Self & $-0.133^{* * *}$ \\
& $(0.0313)$ \\
Informal_Procedure & $-0.0880^{* *}$ \\
TCCLibIndividual & $(0.0323)$ \\
& -0.0807 \\
TCCLibRepSelf & $(0.0538)$ \\
& $0.0939^{* *}$ \\
TCCLibInformal & $(0.0378)$ \\
Constant & 0.0582 \\
Observations & $(0.0400)$ \\
$R^{2}$ & $0.636^{* * *}$
\end{tabular}

TCC $=$ Tax Court of Canada.

$\mathrm{TP}=$ taxpayer.

${ }^{* * *} p<0.01,{ }^{* *} p<0.05,{ }^{*} p<0.1$.

Note: Robust standard errors in parentheses. 


\section{TABLE B3 Influences on Likelihood of Appeal}

(1)

Variables

Appealed_To_FCA

\begin{tabular}{|c|c|}
\hline TCC_Pro_Taxpayer & $\begin{array}{c}-0.0811^{\text {*** }} \\
(0.0119)\end{array}$ \\
\hline TCCLiberalAppt & $\begin{array}{r}-0.0298^{*} \\
(0.0153)\end{array}$ \\
\hline Yrs_TCC_Exp & $\begin{array}{c}-0.00109 \\
(0.00123)\end{array}$ \\
\hline TCC_Tax_Professional & $\begin{array}{c}0.00234 \\
(0.0170)\end{array}$ \\
\hline TCC_Private_Practice & $\begin{array}{c}0.0257 \\
(0.0170)\end{array}$ \\
\hline TCC_Public_Sector & $\begin{array}{c}0.00221 \\
(0.0172)\end{array}$ \\
\hline TCC_Academic & $\begin{array}{c}0.00940 \\
(0.0181)\end{array}$ \\
\hline TCCGender & $\begin{array}{c}0.00880 \\
(0.0114)\end{array}$ \\
\hline TP_Private_Corp & $\begin{array}{c}-0.0224 \\
(0.0200)\end{array}$ \\
\hline TP_Public_Corp & $\begin{array}{l}0.383^{* * *} \\
(0.108)\end{array}$ \\
\hline TP_Other & $\begin{array}{c}0.0465 \\
(0.0477)\end{array}$ \\
\hline WinPrivCorp & $\begin{array}{c}0.0217 \\
(0.0229)\end{array}$ \\
\hline WinPubCorp & $\begin{array}{c}-0.193^{*} \\
(0.0950)\end{array}$ \\
\hline WinOtherParty & $\begin{array}{c}-0.109^{*} \\
(0.0603)\end{array}$ \\
\hline Rep_Counsel & $\begin{array}{c}0.0250 \\
(0.0201)\end{array}$ \\
\hline Rep_AgentOther & $\begin{array}{c}-0.0165 \\
(0.0151)\end{array}$ \\
\hline General_Procedure & $\begin{array}{c}0.154^{* * *} \\
(0.0207)\end{array}$ \\
\hline Other_Procedure & $\begin{array}{c}-0.0299^{* *} \\
(0.0131)\end{array}$ \\
\hline Prov_Quebec & $\begin{array}{c}0.00320 \\
(0.0207)\end{array}$ \\
\hline Prov_BC & $\begin{array}{c}0.0335 \\
(0.0212)\end{array}$ \\
\hline
\end{tabular}




\section{TABLE B3 Concluded}

(1)

Variables

Appealed_To_FCA

\begin{tabular}{lc}
\hline Prov_Alberta & -0.0180 \\
& $(0.0276)$ \\
Prov_Sask & $1.41 \mathrm{e}-05$ \\
& $(0.0257)$ \\
Prov_Man & 0.0481 \\
& $(0.0375)$ \\
Prov_NB & -0.0230 \\
& $(0.0234)$ \\
OtherProvTerr & 0.0316 \\
& $(0.0295)$ \\
MultiDayHearing & $0.0963^{\text {*** }}$ \\
& $(0.0270)$ \\
Constant & $0.101^{\text {*** }}$ \\
Observations & $(0.0305)$ \\
$R^{2}$ & 3,411 \\
\end{tabular}

$\mathrm{FCA}=$ Federal Court of Appeal.

TCC $=$ Tax Court of Canada.

$\mathrm{TP}=$ taxpayer.

${ }^{* * *} p<0.01,{ }^{* *} p<0.05,{ }^{*} p<0.1$

Note: Robust standard errors in parentheses. 


\section{TABLE B4 Influence on Affirmation Rates (No Panel Effects)}

\begin{tabular}{|c|c|}
\hline Variables & (1) vote_fca_judge_affirm \\
\hline TCC_Pro_Taxpayer & $\begin{array}{c}-0.332^{* * *} \\
(0.0749)\end{array}$ \\
\hline TP_Private_Corp & $\begin{array}{c}0.0559 \\
(0.0713)\end{array}$ \\
\hline TP_Public_Corp & $\begin{array}{c}-0.171 \\
(0.136)\end{array}$ \\
\hline TP_Other & $\begin{array}{c}-0.0107 \\
(0.0948)\end{array}$ \\
\hline WinPrivCorp & $\begin{array}{c}0.268^{\star *} \\
(0.133)\end{array}$ \\
\hline WinPubCorp & $\begin{array}{l}0.381^{* *} \\
(0.190)\end{array}$ \\
\hline WinOtherParty & $\begin{array}{r}0.0307 \\
(0.358)\end{array}$ \\
\hline TCC_Rep_Counsel & $\begin{array}{c}-0.105^{*} \\
(0.0576)\end{array}$ \\
\hline TCC_Rep_AgentOther & $\begin{array}{r}-0.169^{* *} \\
(0.0688)\end{array}$ \\
\hline General_Procedure & $\begin{array}{c}0.0650 \\
(0.0548)\end{array}$ \\
\hline Other_Procedure & $\begin{array}{c}0.0795 \\
(0.0911)\end{array}$ \\
\hline TCCLiberalAppt & $\begin{array}{r}-0.0340 \\
(0.0974)\end{array}$ \\
\hline TCC_Tax_Professional & $\begin{array}{c}-0.0282 \\
(0.0576)\end{array}$ \\
\hline TCC_Private_Practice & $\begin{array}{c}0.0369 \\
(0.0667)\end{array}$ \\
\hline TCC_Public_Sector & $\begin{array}{c}0.0192 \\
(0.0497)\end{array}$ \\
\hline Yrs_TCC_Exp & $\begin{array}{c}-0.00106 \\
(0.00478)\end{array}$ \\
\hline FCA_Judge_Lib & $\begin{array}{c}0.0797 \\
(0.0929)\end{array}$ \\
\hline Different_Party & $\begin{array}{c}0.00239 \\
(0.0921)\end{array}$ \\
\hline Constant & $\begin{array}{l}0.788^{* * *} \\
(0.142)\end{array}$ \\
\hline Observations & 1,209 \\
\hline$R^{2}$ & 0.098 \\
\hline
\end{tabular}

FCA $=$ Federal Court of Appeal.

TCC $=$ Tax Court of Canada.

$\mathrm{TP}=$ taxpayer.

${ }^{* * *} p<0.01,{ }^{* *} p<0.05,{ }^{*} p<0.1$.

Note: Robust standard errors in parentheses. 
TABLE B5 Influence on Affirmation Rates (Panel Effects) Using Judge Votes

\begin{tabular}{|c|c|}
\hline Variables & vote_fca_judge_affirm \\
\hline TCC_Pro_Taxpayer & $\begin{array}{c}-0.334^{* * *} \\
(0.0756)\end{array}$ \\
\hline TP_Private_Corp & $\begin{array}{c}0.0503 \\
(0.0717)\end{array}$ \\
\hline TP_Public_Corp & $\begin{array}{c}-0.170 \\
(0.134)\end{array}$ \\
\hline TP_Other & $\begin{array}{c}-0.00516 \\
(0.0942)\end{array}$ \\
\hline WinOtherParty & $\begin{array}{r}0.0307 \\
(0.375)\end{array}$ \\
\hline WinPubCorp & $\begin{array}{c}0.378^{* *} \\
(0.190)\end{array}$ \\
\hline WinPrivCorp & $\begin{array}{c}0.280^{* *} \\
(0.134)\end{array}$ \\
\hline TCC_Rep_Counsel & $\begin{array}{c}-0.107^{*} \\
(0.0574)\end{array}$ \\
\hline TCC_Rep_AgentOther & $\begin{array}{r}-0.167^{* *} \\
(0.0695)\end{array}$ \\
\hline General_Procedure & $\begin{array}{c}0.0707 \\
(0.0547)\end{array}$ \\
\hline Other_Procedure & $\begin{array}{c}0.0774 \\
(0.0905)\end{array}$ \\
\hline TCCLiberalAppt & $\begin{array}{c}-0.0418 \\
(0.0972)\end{array}$ \\
\hline TCC_Tax_Professional & $\begin{array}{r}-0.0300 \\
(0.0576)\end{array}$ \\
\hline TCC_Private_Practice & $\begin{array}{c}0.0355 \\
(0.0680)\end{array}$ \\
\hline TCC_Public_Sector & $\begin{array}{c}0.0199 \\
(0.0501)\end{array}$ \\
\hline Yrs_TCC_Exp & $\begin{array}{c}-0.00164 \\
(0.00481)\end{array}$ \\
\hline Different_Party & $\begin{array}{c}0.00711 \\
(0.0905)\end{array}$ \\
\hline FCA_Cons_on_Three_Conservative_Panel & $\begin{array}{r}0.0185 \\
(0.176)\end{array}$ \\
\hline FCA_Cons_Majority_with_Liberal & $\begin{array}{c}0.0160 \\
(0.0491)\end{array}$ \\
\hline FCA_Liberal_Majority_with_Conservative & $\begin{array}{c}0.0389 \\
(0.0430)\end{array}$ \\
\hline
\end{tabular}

(Table B5 is concluded on the next page.) 


\section{TABLE B5 Concluded}

\begin{tabular}{lc}
\hline Variables & vote_fca_judge_affirm \\
\hline FCA_Lone_Conservative & 0.0309 \\
Constant & $(0.0435)$ \\
& $0.853^{* * *}$ \\
Observations & $(0.108)$ \\
$R^{2}$ & 1,209 \\
\hline
\end{tabular}

FCA $=$ Federal Court of Appeal.

TCC $=$ Tax Court of Canada.

$\mathrm{TP}=$ taxpayer.

${ }^{* * *} p<0.01,{ }^{* *} p<0.05,{ }^{*} p<0.1$.

Note: Robust standard errors in parentheses.

TABLE B6 Influence on Affirmation Rates (Panel Effects) Using Case Outcomes (Base Case-All Liberal Panel)

\begin{tabular}{lc}
\hline Variables & fca_affirmed_tcc \\
\hline TCC_Pro_Taxpayer & $-0.224^{* *}$ \\
TCCLiberalAppt & $(0.103)$ \\
& $-0.148^{* *}$ \\
Yrs_TCC_Exp & $(0.0730)$ \\
& -0.000710 \\
TCC_Tax_Professional & $(0.00476)$ \\
TCC_Private_Practice & -0.0116 \\
& $(0.0590)$ \\
TCC_Public_Sector & 0.00836 \\
ProTP_TCCJudgeLib & $(0.0669)$ \\
FCA_Panel_Percentage_Conservative & 0.0258 \\
TCCLib_FCA_Panel_Percentage_Conservative & $(0.0510)$ \\
ProTP_PercentCon & -0.00248 \\
TP_Private_Corp & $(0.120)$ \\
TP_Public_Corp & -0.0582 \\
TP_Other & $(0.126)$ \\
& $0.433^{* * *}$ \\
& $(0.166)$ \\
& $-0.412^{*}$ \\
& $(0.214)$ \\
& 0.0480 \\
& $(0.0730)$ \\
& -0.154 \\
& $(0.128)$ \\
& -0.00882 \\
& $(0.0932)$ \\
\hline
\end{tabular}

(Table B6 is concluded on the next page.) 
TABLE B6 Concluded

\begin{tabular}{lc}
\hline Variables & fca_affirmed_tcc \\
\hline WinPrivCorp & $0.274^{* *}$ \\
WinPubCorp & $(0.137)$ \\
& $0.362^{*}$ \\
WinOtherParty & $(0.184)$ \\
& 0.00985 \\
Rep_Counsel & $(0.326)$ \\
& $-0.128^{* *}$ \\
Rep_AgentOther & $(0.0570)$ \\
& $-0.175^{* *}$ \\
General_Procedure & $(0.0697)$ \\
& 0.0637 \\
Other_Procedure & $(0.0552)$ \\
Constant & 0.0480 \\
Observations & $(0.0975)$ \\
$R^{2}$ & $0.894^{* * *}$ \\
\hline
\end{tabular}

$\mathrm{FCA}=$ Federal Court of Appeal.

TCC $=$ Tax Court of Canada.

$\mathrm{TP}=$ taxpayer.

${ }^{* * *} p<0.01,{ }^{* *} p<0.05,{ }^{*} p<0.1$.

Note: Robust standard errors in parentheses. 
